\title{
Therapeutic applications and biological activities of bacterial bioactive extracts
}

\author{
Zainab Abdelghani ${ }^{1} \cdot$ Nancy Hourani ${ }^{2}\left(\mathbb{D} \cdot\right.$ Zahraa Zaidan $^{1} \cdot$ Ghassan Dbaibo $^{2,3} \cdot$ Marguerite Mrad $^{2,3}$. \\ Rouba Hage-Sleiman ${ }^{1}$
}

Received: 1 April 2021 / Revised: 24 July 2021 / Accepted: 27 July 2021 / Published online: 9 August 2021

(c) The Author(s), under exclusive licence to Springer-Verlag GmbH Germany, part of Springer Nature 2021

\begin{abstract}
Bacteria are rich in a wide variety of secondary metabolites, such as pigments, alkaloids, antibiotics, and others. These bioactive microbial products serve a great application in human and animal health. Their molecular diversity allows these natural products to possess several therapeutic attributes and biological functions. That's why the current natural drug industry focuses on uncovering all the possible ailments and diseases that could be combated by bacterial extracts and their secondary metabolites. In this paper, we review the major utilizations of bacterial natural products for the treatment of cancer, inflammatory diseases, allergies, autoimmune diseases, infections and other diseases that threaten public health. We also elaborate on the identified biological activities of bacterial secondary metabolites including antibacterial, antifungal, antiviral and antioxidant activities all of which are essential nowadays with the emergence of drug-resistant microbial pathogens. Throughout this review, we discuss the possible mechanisms of actions in which bacterial-derived biologically active molecular entities could possess healing properties to inspire the development of new therapeutic agents in academia and industry.
\end{abstract}

Keywords Secondary metabolites $\cdot$ Bacterial extracts $\cdot$ Anti-cancer $\cdot$ Immunomodulation $\cdot$ Antibacterial $\cdot$ Antifungal . Antiviral · Antioxidant

\section{Introduction}

Secondary metabolites originate as natural products from a variety of sources, including terrestrial plants, animals, marine organisms, terrestrial vertebrates and invertebrates, and microorganisms (Chin et al. 2006). These molecules are structurally and chemically diverse and act as a remarkable

Communicated by Erko Stackebrandt.

Marguerite Mrad

mm220@aub.edu.lb

Rouba Hage-Sleiman

rouba.hagesleiman@ul.edu.lb

1 Department of Biology, Faculty of Sciences, Lebanese University, Hadath, Lebanon

2 Department of Biochemistry and Molecular Genetics, Faculty of Medicine, American University of Beirut, Beirut, Lebanon

3 Department of Pediatrics and Adolescent Medicine, Center for Infectious Diseases Research, Faculty of Medicine, American University of Beirut, Beirut, Lebanon class of therapeutics to heal a myriad of diseases. The earliest natural products found to improve human health were first described in ancient Mesopotamia from 2900 to 2600 BCE (Siddiqui et al. 2014). Given the historical successes of natural products, large pharmaceutical companies invested in this traditional domain (Maher 2020) and approximately $60 \%$ of small-molecule approved drugs are related to natural products (Patridge et al. 2016).

In 1928, Alexander Fleming discovered penicillin from Penicillium chrysogenum previously known as Penicillium notatum which marked the significant shift from plants to microorganisms as a source of natural products (Gaynes 2017). Since then, the utilization of microorganism-derived compounds has spread in medicine, agriculture, the food industry and scientific research (Choi and Oh 2015). Nowadays, the chemical and biological tools allowed scientists to uncover the biological effects of natural compounds on the human body, as well as to apply possible synergies, which help in developing new therapies (Ji et al. 2009). Natural compounds have been investigated for their pharmacological potency, safety and ability to alleviate the symptoms of many diseases by modulating immune system effector cells and 
molecules (Mok et al. 2020). Since many anti-cancer drugs showed nonspecific toxicity against normal cells (Yingchoncharoen et al. 2016), ongoing researches aim to discover selective anti-cancer treatments with minimal undesired side effects (Cragg et al. 2009; Pucci et al. 2019).

Herein, we summarize the biological activities and applications of a variety of bacterial extracts and their secondary metabolites and review the mechanisms of action behind their therapeutic effects. We cover past and current studies that describe the use of these biological products in treating cancer, inflammatory diseases, allergies, autoimmune diseases, infections and others. In addition, we discuss the antibacterial, antifungal, antiviral and antioxidant activities of some natural products. Our aim is to highlight the role of bacterial extracts and their identified secondary metabolites in the modern drug industry and their importance as potential therapeutic agents.

\section{Anti-cancer activity of bacterial extracts}

Cancer is the most significant cause of death worldwide (Siegel et al. 2020). In 2018, 9.6 million people were estimated to have died from different types of cancer (Dube et al. 2019). This number is expected to continue rising to 13.1 million deaths in 2030 (Lichtman 2013). Cancer is characterized by an uncontrolled and deregulated cell growth, immortalization, invasion, angiogenesis and metastasis (Chang et al. 2011). Cancer can be treated with surgery, traditional chemotherapy, radiation therapy and immunotherapy. Since many cancers cells, not particularly tumors developed resistance to apoptosis-inducing treatments (Lalitha et al. 2016), the search for natural products from plants, animals and microorganisms have been investigated over the past decades for cancer prevention, therapy and minimization of cancer prevalence (Tan et al. 2019). Microorganisms, especially those living under harsh conditions, were found to be potent and valuable reservoirs of natural anti-cancer metabolites due to their novel and distinctive compounds (Safarpour et al. 2019). A total of $70 \%$ of microbial secondary compounds are produced by Actinomycetes, $7 \%$ by Bacillus and 1-2\% by other bacteria (Khalifa et al. 2019). The anti-cancer compounds derived from microorganisms are summarized in Table 1.

\section{Actinomycetes}

Actinomycetes are filamentous gram-positive bacteria that belong to the phylum Actinobacteria known for its high genomic and metabolic diversity (Sudha and Masilamani 2012). Actinomycetes are the most promising source of anti-cancer chemotherapeutics and they account for approximately $45 \%$ of all secondary metabolites, $80 \%$ of which are produced by the largest known genus of Actinobacteria, Streptomyces (Dhaneesha et al. 2017). Actinomycetes-derived anti-cancer drugs include anthracyclines (aclarubicin, daunomycin and doxorubicin), peptides (bleomycin and actinomycin D), aureolic acids (mithramycin), enediynes (neocarzinostatin), antimetabolites (pentostatin), carzinophilin, mitomycins and others (Krishnan et al. 2014).

Bleomycin produced by Streptoalloteichus hindustanus has been used for its potential therapeutic activity against different types of cancer including testicular cancer, ovarian cancer, Hodgkin's lymphoma (Demain and Vaishnav 2011). It acts by inducing DNA strand breaks, and some studies suggest that bleomycin also inhibits the incorporation of thymidine into DNA strands (Hecht 2000). Moreover, a diterpenoid derivative was extracted from Actinobacteria isolated from Chinese mangrove soil of Zhangzhou, Micromonospora zhangzhouensis HM134 and showed in vitro anti-proliferative activity against liver cancer HepG2, colon cancer HCT-116 and lung cancer A549 cells (Fu et al. 2020). A cyclic peptide antibiotic, urukthapelstatin A, isolated from Merchercharimyces asporophorigenes YM11-542 was found to inhibit the growth of A549 cells and exert cytotoxicity against multiple cancer cell lines (Matsuo et al. 2007). In addition, thiocoraline, a depsipeptide derived from Micromonospora marina, inhibited the synthesis of RNA in murine leukemia P388, lung cancer A549 and murine erythroleukemia MEL cell lines (Romero et al. 1997) and induced cell cycle arrest at G1 phase in LOVO and SW620 colon cancer cell lines (Erba et al. 1999).

Several studies have focused on the therapeutic activity of trehalose, a disaccharide isolated from a variety of organisms, in cancer and neurodegenerative diseases. In fact, trehalose was found to induce autophagy in primary keratinocytes and in $\mathrm{HaCaT}$ human keratinocyte cell line independently of mTOR inhibition (Chen et al. 2016). It also interfered with the assembly of the dysregulated RNA-binding protein complex (stress granules) through enhancing the phosphorylation of the $\alpha$ subunit of eukaryotic initiation factor 2 (eIF2), which prevents abnormal protein translation and aggregation in neurodegenerative diseases like amyotrophic lateral sclerosis (ALS) (Mazroui et al. 2006). On the other hand, trehalose enhanced post-stress p-eIF $2 \alpha$ dephosphorylation and restoration of the polysome translation allowing stress recovery (Dimasi et al. 2017). Enzyme-stable trehalose analogs lentztrehaloses $\mathrm{A}, \mathrm{B}$ and $\mathrm{C}$ were isolated from the Actinomycete strain Lentzea sp. ML457-mF8 and demonstrated an autophagic activity in human melanoma and ovarian cancer cells with an improved bioavailability compared to trehalose. They also showed potential activity against neurodegenerative diseases and other autophagyrelated diseases, such as diabetes, arteriosclerosis and heart diseases (Wada et al. 2015). 


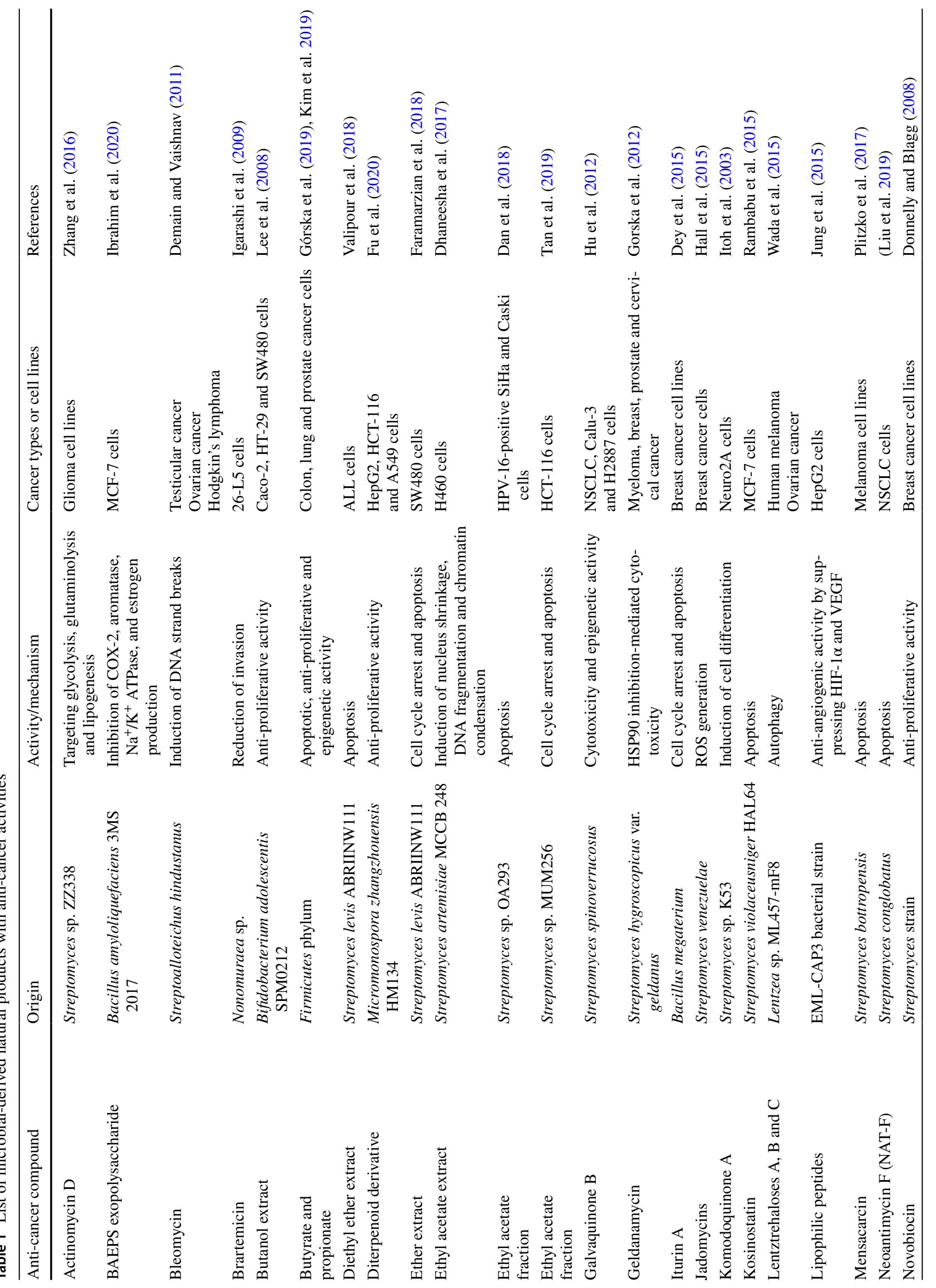




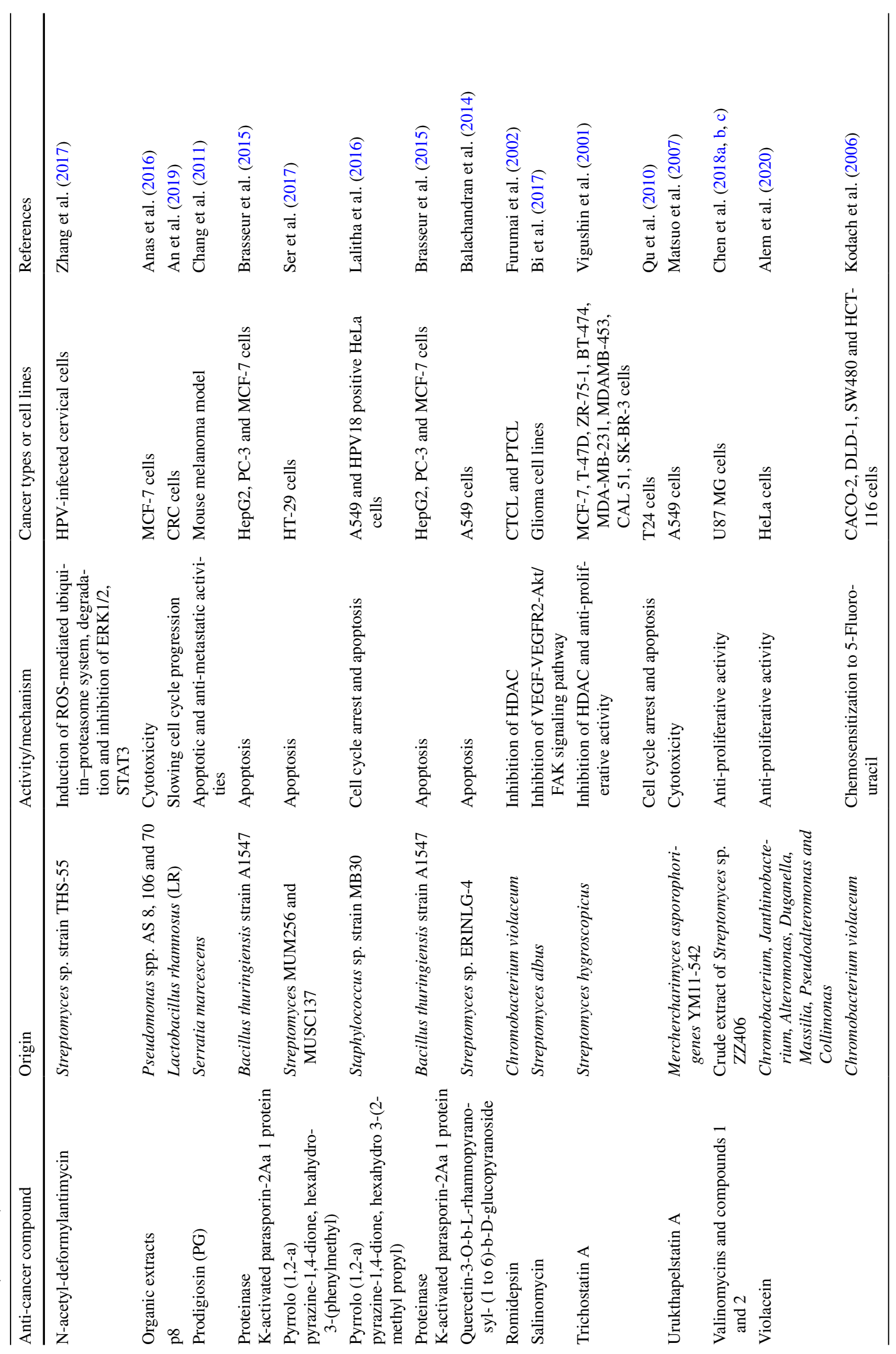




\section{Streptomyces}

Streptomyces are filamentous, mainly gram-positive bacteria that belong to the order Actinomycetales (Strobel et al. 2005). Streptomyces is the largest genus of Actinobacteria that comprises about 780 species that colonize marine and terrestrial habitats (Law et al. 2017). More than $50 \%$ of the discovered antibiotics have been isolated from Streptomyces species (Hu et al. 2017). In fact, Streptomyces produce angiogenesis inhibitors, antifungal, anti-parasitic, antiviral, antioxidant, anti-inflammatory, immunosuppressive, cytotoxic and cytostatic compounds (Law et al. 2017). Natural products derived from these species have great potential for the discovery of anti-cancer drugs (Valipour et al. 2018) such as saptomycins, bleomycin, cremeomycin, clecarmycins, moromycins $\mathrm{A}$ and $\mathrm{B}$, mitomycin $\mathrm{C}$, pentostatin, saquayamycin B and aclarubicin (Krishnan et al. 2014). These compounds act by either inducing apoptosis, inhibiting enzymes involved in oncogenic signal transduction pathways, causing mitochondrial membrane permeabilization (MMP), inhibiting angiogenesis, cellular differentiation, or serving as DNA intercalating agents (Aftab et al. 2015). Furthermore, elaiophylin, isolated from Streptomyces melanosporus, blocked angiogenesis both in vitro and in vivo by downregulating VEGFR2 pathway in endothelial cells and hypoxia-inducible factor-1 $\alpha$ (HIF-1 $\alpha$ ) levels in tumor cells leading to tumor growth reduction (Lim et al. 2018).

\section{Brain cancer}

Actinomycin D from Streptomyces parvulus is the first antibiotic to clinically treat Wilms' tumor, childhood rhabdomyosarcoma, Ewing's sarcoma and metastatic non-seminomatous testicular cancer (Pham et al. 2019). It was found that actinomycin D produced by Streptomyces sp. ZZ338 inhibits the enzymes involved in the regulation of the metabolism of glioma cell lines (Zhang et al. 2016). In addition, valinomycins and new compounds 1 and 2 isolated from the crude extract of Streptomyces sp. ZZ406 cultured in soluble starch and casein liquid medium were found to inhibit the proliferation of glioma U87 MG cells by downregulating glioma metabolic regulators (Chen et al. 2018a, b, c). Moreover, compound 1 also significantly downregulated the expression of tumor glycolytic enzymes such as hexokinase 2 (HK2), 6-phosphofructo-2-kinase/fructose-2,6-biphosphatase 3 (PFKFB3), pyruvate kinase M2 (PKM2) and lactate dehydrogenase 5 (LDH5) (M. Chen et al. 2018a, b, c). Salinomycin, a polyether antibiotic derived from Streptomyces albus, has an anti-cancer activity against human glioma growth by inhibiting the VEGF-VEGFR2-Akt/FAK signaling pathway involved in angiogenesis (Bi et al. 2017). Another study has shown that the anthracycline compound, komodoquinone A from Streptomyces sp. K53 has the ability to induce differentiation of Neuro2A neuroblastoma cell line (Itoh et al. 2003).

\section{Lung cancer}

Nucleus shrinkage, DNA fragmentation, and chromatin condensation were detected in H460 human lung cancer cell line treated with the ethyl acetate extract of Streptomyces artemisiae MCCB 248 (Dhaneesha et al. 2017). In addition, neoantimycin F (NAT-F) from Streptomyces conglobatus induced apoptosis in non-small cell lung cancer (NSCLC) cells by triggering loss of the mitochondrial membrane potential (MMP), upregulating pro-apoptotic protein BAX, downregulating anti-apoptotic proteins Bcl-2, Bcl-XL, and Mcl-1, releasing cytochrome $\mathrm{c}$ and activating caspases- 9 and -3 (Liu et al. 2019). It also induced reactive oxygen species (ROS) generation, enhanced the phosphorylation of p38 mitogen-activated protein kinase (p38 MAPK) and c-Jun N-terminal kinase (JNK) and inhibited extracellular signal-regulated kinase (ERK1/2) phosphorylation resulting in MAPK-dependent mitochondria-mediated apoptosis in NSCLC cells (Liu et al. 2019). Anthraquinones are the largest group of naturally occurring quinones isolated mainly from fungal sources, they exhibit a wide range of activities including anti-inflammatory, antimicrobial, antioxidant, antiviral, and antitumor properties. In this concept, several anthraquinone analogs have been isolated from the bacterial source Streptomyces spinoverrucosus, out of which, galvaquinone $\mathrm{B}$ exerted moderate cytotoxicity against different types of cell lung cancer NSCLC, Calu-3 and H2887, and demonstrated epigenetic modulatory properties (Hu et al. 2012). The isolated compound quercetin-3-O-b-L-rhamnopyranosyl-(1 to 6)-b-D-glucopyranoside from soil-derived Streptomyces sp. ERINLG-4 was tested on colorectal and kidney cells but the potent cytotoxic effect was selective to lung cancer by inducing both intrinsic and extrinsic apoptosis via caspase-dependent cytochrome c release in A549 lung cancer cells (Balachandran et al. 2014).

\section{Cervical cancer}

Cervical cancer, specifically HPV-induced cervical cancer, is characterized by changes in PI3K/AKT/mTOR and ERK1/2 signaling pathways that lead to a poor response to cervical cancer treatments. Thus, drugs targeting PI3K/AKT/mTOR pathway are ideal to achieve a better efficacy (Bahrami et al. 2017). A natural product, $n$-acetyl-deformylantimycin (NADA) isolated from a crude extract of Streptomyces sp. strain THS-55 was shown to enhance ROS-mediated ubiquitin-proteasome system (UPS) degradation of oncoproteins E6/E7 in HPV-infected cervical cells resulting in S-phase cell cycle arrest and apoptosis, and inhibiting ERK1/2, STAT3 and PI3K/AKT/mTOR pathway (Zhang et al. 2017). 
One study explained how bioactive compound(s) from ethyl acetate fraction of Streptomyces sp. OA293 induced BAXmediated intrinsic apoptosis with complete inhibition of mTOR signaling pathway in cervical cancer cell lines (HPV16-positive SiHa and Caski) (Dan et al. 2018). Another compound is Geldanamycin (GDA), a benzoquinone ansamycin compound isolated from Streptomyces hygroscopicus var. geldanus, has an anti-cancer activity in multiple myeloma, breast, and prostate cancer (Gorska et al. 2012). It also acts as an inhibitor of the heat shock protein HSP90 and causes cytotoxicity in HPV-18-positive HeLa cells (Khalifa et al. 2019).

\section{Colon cancer}

Ether extract of Streptomyces levis ABRIINW111 showed an increase in p53 expression, cell cycle arrest in G1 and G2/M phases and apoptosis in SW480 colon cancer cell line (Faramarzian et al. 2018). Metabolites from this extract decreased anti-apoptotic K-RAS and Bcl-2 proteins expression and increased pro-apoptotic p53 protein expression (Fatourachi et al. 2018). Similarly, ethyl acetate fraction of Streptomyces sp. MUM256 filtrate caused G1 and G2/M arrest, p21 and p53 upregulation, cyclin B1, CDK2, CDK4, cdc25 A phosphatase downregulation, and intrinsic apoptosis in HCT-116 colon cancer cells (Tan et al. 2019). Pyrrolo (1,2-a) pyrazine-1,4-dione, hexahydro-3-(phenylmethyl)-, a cyclic dipeptide found in extracts of Streptomyces MUM256 and MUSC137 induced PARP cleavage and increased caspase-3 activity resulting in apoptosis in HT-29 colon cancer cells (Ser et al. 2017). Another study reported that the latter cyclic dipeptides have the ability to induce the collapse of mitochondrial membrane potential MMP, DNA fragmentation and cell cycle arrest in the subG1 phase in Caco-2 colon cancer cells (Teng Hern et al. 2019).

\section{Blood cancer}

Metabolites derived from Streptomyces sp. SY-103 have been shown to induce apoptosis in human leukemic cells upon treatment; through activating caspase- 3 and inactivating AKT (Faramarzian et al. 2018). Some of these metabolites are pure cytotoxic compound (PCC), spicamycin and its derivative KRN5500, which were found to induce apoptosis by decreasing expression of Bcl-2 and modulating the normal localization pattern of promyelocytic leukemia protein (PML) from speckled pattern to microspeckled pattern in myeloid and lymphoid leukemic cells (Jeong et al. 2010; Zhang et al. 2000). Similarly, diethyl ether extract of Streptomyces levis ABRIINW111 upregulated BAX and downregulated Bcl-2 resulting in the induction of $\mathrm{p} 53$-dependent apoptosis in acute lymphoblastic leukemia (ALL) cells (Valipour et al. 2018).
Actinomycetes-derived anthracyclines are antitumor antibiotics that mainly perform their anti-cancer activity via topoisomerase II inhibition (Khalifa et al. 2019). For instance, daunorubicin and doxorubicin are two FDA approved drugs from the anthracyclines family used to treat acute lymphoblastic or myeloblastic lymphoma (Di Marco et al. 1981) by acting as DNA/RNA intercalating agents, generating reactive free radicals, and causing DNA doublestrand breaks by the expulsion of histones from chromatin (Pang et al. 2015).

\section{Other types of cancer}

Mensacarcin isolated from Streptomyces bottropensis was shown to induce caspase-3/7-dependent apoptosis and mitochondrial dysfunction with selective cytotoxicity against melanoma cell lines that hold a BRAFV600E mutation associated with drug resistance (Plitzko et al. 2017). Moreover, Streptochlorin from Streptomyces sp. induced apoptosis in human hepatocarcinoma cells via the mitochondrial pathway (Valipour et al. 2018). Kosinostatin, a quinocycline antibiotic derived from Streptomyces violaceusniger HAL64, was shown to induce p53-dependent apoptosis in MCF-7 mammary carcinoma cell line (Rambabu et al. 2015). Several studies identified Salinomycin as a strong anti-cancer agent against breast, colorectal, lung, gastric, pancreatic and osteosarcoma (Safarpour et al. 2019) by inducing DNA damage, autophagy, mitophagy, upregulation of death receptors and hyperpolarization of mitochondria ( $\mathrm{Li}$ et al. 2016). Novobiocin isolated from a Streptomyces strain, in anti-proliferative assays against breast cancer cell lines, showed the ability to bind to the C-terminus of Hsp90 resulting in the release and destruction of Hsp90-dependent client proteins responsible for the hallmarks of cancer such as ErbB2, mutant p53, Raf-1, HDAC6, AKT and c-Met receptor tyrosine kinase (Donnelly and Blagg 2008).

\section{Endophytic actinobacteria and other bacterial species}

Endophytic microorganisms are endosymbiotic organisms, mainly fungi and bacteria that colonize plant tissues (EkRamos et al. 2019). Some of the endophyte-derived secondary metabolites include alkaloids, benzopyranones, chinones, flavonoids, phenolic acids, quinones, steroids, terpenoids, teralones and xanthones (Pimentel et al. 2011). These bioactive metabolites can act as antibiotics, antimycotics, immunosuppressants and anti-cancer treatments (Strobel et al. 2005).

Bacillus and Streptomyces species are the most abundant metabolite-producing gram-positive bacterial endophytes (Ek-Ramos et al. 2019). Exopolysaccharides isolated from Bacillus amyloliquefaciens sp., an endophytic 
microorganism hosted in Ophiopogon japonicas plant, demonstrated antitumor activity against gastric carcinoma cell lines (Abdalla \& Matasyoh, 2014). BAEPS, an acidic exopolysaccharide produced from Marine Bacillus amyloliquefaciens 3MS 2017, demonstrated both prophylactic and curative potential against 7,12-dimethylebenz-(a)anthracene (DMBA)-induced breast cancer in female rats through inhibition of COX-2, aromatase, $\mathrm{Na}^{+} / \mathrm{K}^{+}$ATPase, and estrogen production (Ibrahim et al. 2020). Crude extracts from Acinetobacter guillouiae, an endophytic organism isolated from Crinum macowanii Baker bulbs, were shown to reduce the growth of U87MG glioblastoma cell line by half (Sebola et al. 2019b). Moreover, lipophilic peptides derived from the endophytic EML-CAP3 bacterial strain isolated from Capsicum annum $L$. exerted an anti-angiogenic activity by suppressing hypoxia-inducible factor- $1 \alpha$ (HIF- $1 \alpha)$ and its target gene vascular endothelial growth factor (VEGF) in human hepatocellular carcinoma cell line HepG2 and inhibiting the proliferation of human umbilical vein endothelial cells (HUVECs) (Jung et al. 2015). Brartemicin, a trehalosederived compound isolated from endophytic Nonomuraea sp. associated with Artemisia vulgaris, limited the invasion of murine colon carcinoma 26-L5 cells (Igarashi et al. 2009). Other chemotherapeutic anti-cancer compounds include Paclitaxel (Taxol), a drug produced by endophytic actinomycete strains BPSAC77, BPSAC101, and BPSAC121 as well as from Kitasatospora sp., an endophytic actinomycete associated with the Taxus baccata plant, Kaempferol, a phenolic compound present in the endophytic actinomycete strains BPSAC77, BPSAC101, and Tc052, and L-asparaginase produced by endophytic Bacillus licheniformis, Bacillus pseudomycoides and Paenibacillus denitriformis (Passari et al. 2017; Singh et al. 2017). Jadomycins, isolated from Streptomyces venezuelae, showed a cytotoxicity against multidrug-resistant MCF7 breast cancer cells that overexpress ATP-binding cassette (ABC) drug efflux transporters $\mathrm{ABCB} 1, \mathrm{ABCC} 1$, and $\mathrm{ABCG} 2$. Thus, this suggests their potential use as chemosensitizing agents (Issa et al. 2014). Another study demonstrated that jadomycin cytotoxicity in both drug-sensitive and taxol-resistant MCF-7 cells is ROSmediated and requires the presence of copper (Hall et al. 2015).

Epothilone, from myxobacterium Sorangium cellulosum prevented microtubule depolymerization resulting in cell cycle arrest at G2/M interphase in P-glycoproteinexpressing multiple-drug-resistant tumor cell lines (Molnár et al. 2000). Pyrrolo (1,2-a) pyrazine-1,4-dione, hexahydro 3-(2-methyl propyl) (PPDHMP) derived from the marine bacterium Staphylococcus sp. strain MB30, isolated from the deep-sea sediment of Bay of Bengal, India, was shown to cause G1 cell cycle arrest, apoptotic morphological changes, caspase- 9 and 3 activation, PARP cleavage and anti-apoptotic proteins downregulation in lung cancer A549 and HPV18 positive human cervix cancer HeLa cells (Lalitha et al. 2016). Induction of apoptosis was also obtained upon the treatment of U-87MG glioblastoma cells with Bacillus-derived cyclo (L-Pro-L-Phe), via AKT1 inactivation (Hong et al. 2008; Teng Hern et al. 2019). Similarly, proteinase $\mathrm{K}$-activated parasporin-2Aa 1 protein isolated from Bacillus thuringiensis strain A1547 induced apoptosis in human liver HepG2, human prostate PC-3 and mammary carcinoma MCF-7 cancer cells via caspases-3/7 and poly (ADP-ribose) polymerase (PARP) cleavage, and inhibited the survival pathways through downregulation of AKT and ERK1/2 (Brasseur et al. 2015). Iturin A, a lipopeptide molecule extracted from Bacillus megaterium, was shown to upregulate BAX, downregulate Bcl-2, Bcl-xl, and Mcl-1 and inhibit the phosphorylation of AKT and its downstream proteins FoxO3a and GSK3B leading to cell cycle arrest and apoptosis in breast cancer cell lines (Dey et al. 2015). Anionic exopolysaccharide derived from Nitratireductor $\mathrm{sp}$. strain PRIM-31 was shown to bind the epidermal growth factor (EGF) released by the brain tumor, prevent EGF receptor phosphorylation, and halt the AKT/PI3K pathway, thus acting as a potential brain anti-tumor drug (Abdelnasser et al. 2017).

Prodigiosin (PG), the red pigment produced by Serratia marcescens and other gram-negative bacteria, possesses a p53-independent apoptotic activity on malignant cells as well as anti-metastatic activity in a mouse melanoma model via matrix RhoA and metalloproteinase-2 inhibition (Chang et al. 2011). In addition, this compound prevented metastasis in C57BL6 mice inoculated with the syngeneic B16BL6 melanoma cells and limited the migration/invasion of the highly metastatic lung carcinoma 95-D cells through downregulation of cell invasion promoters RhoA and matrix metalloproteinase-2 (MMP-2) (Zhang et al. 2005). Interestingly, PG induced identical cytotoxicity in cell lines overexpressing multidrug-resistant pumps when compared to their parental counterparts; and unlike classical chemotherapies (daunorubicin or mitoxantrone), $\mathrm{ABC}$ transporters were unable to efflux PG out of gastric carcinoma and epithelial ovarian cells thus circumventing the problem of drug resistance (Elahian et al. 2013). The organic extracts from Pseudomonas spp. AS 8, 106 and 70 retrieved from sediments of the Arabian Sea exhibited cytotoxicity against MCF-7 cells with 41,50 , and $45 \%$ mortality, respectively (Anas et al. 2016). Moreover, several bacterial extracts (lipophilic and hydrophilic) were obtained from the brine-seawater interface of the Red Sea and were tested for cytotoxicity. Among twelve extracts with demonstrated cytotoxicity at $24 \mathrm{~h}$, P1-37B and P1-37A isolated from Halomonas and P1-17B from Sulfitobacter exhibited the most potent effect against mammary carcinoma MCF-7, HPV18 positive human cervix HeLa and human prostate DU145 cancer cells (Sagar et al. 2013). 
Recently, violacein, a secondary metabolite pigment produced by many bacterial strains including Chromobacterium, Janthinobacterium, Alteromonas, Duganella, Massilia, Pseudoalteromonas and Collimonas, has been evaluated for its anti-cancer effect on HeLa cells and showed an antiproliferative activity. Moreover, it sensitized HeLa cells to chemotherapeutic agent cisplatin (Alem et al. 2020). In addition to its effect on cervical cancer, violacein has been shown to sensitize CACO-2, DLD-1, SW480 and HCT-116 colorectal cancer cell lines to 5-fluorouracil (5-FU), a commonly used chemotherapeutic agent (Kodach et al. 2006).

Romidepsin (FK228, depsipeptide) is an anti-tumor antibiotic originally derived from Chromobacterium violaceum. It received FDA approval for the treatment of cutaneous $\mathrm{T}$ cell lymphoma (CTCL) and peripheral T cell lymphoma (PTCL) (Moskowitz and Horwitz 2017). FK228 was later reported to have a histone deacetylase (HDAC) inhibitory activity. In fact, FK228 is converted to its reduced active form, exposing its sulfhydryl group which binds to the zinc ion of the HDAC active site and inhibits it (Furumai et al. 2002). Another HDAC inhibitor is trichostatin A (TSA), a hydroxamic acid that was first isolated from Streptomyces hygroscopicus in 1976 and described as antifungal and antibacterial agent (Singh et al. 2010). Later, TSA was found to significantly inhibit the activity of class I, II, and IV HDACs and the proliferation of eight breast cancer cell lines (MCF7, T-47D, ZR-75-1, BT-474, MDA-MB-231, MDAMB-453, CAL 51, and SK-BR-3) (Vigushin et al. 2001). Moreover, TSA was able to induce cell cycle arrest of bladder cancer T24 cells in the G0/G1 phase and cause apoptosis of cancer cells (Qu et al. 2010). In A549 cells, the combination of TSA and cisplatin produced an enhanced synergistic anti-cancer effect compared to using either of them alone (Zhang et al. 2015). However, its application in clinical trials remains hindered due to its toxicity (Vanhaecke et al. 2004).

\section{Human microbiota metabolites}

The gastro-intestinal tract (GI) is the organ most colonized with microorganisms in the human body, dominated by bacteria most of which (90\%) belong to the phyla Bacteroidetes and Firmicutes, with the colon demonstrating the highest bacterial count $\left(10^{11}\right.$ bacteria/ml) (Coleman and Haller 2018). GI tract microbiota plays a protective role where alterations in their structure and abundance (dysbiosis) have been related to pathogenic cases including inflammation and carcinogenesis, mainly colorectal cancer (CRC) (Coleman and Haller 2018). The mechanisms of action of microbiota include the modulation of anti-inflammatory cytokines, the alteration in prostaglandin secretion and the activation of phagocytes that in turn eliminate cancer cells at the early stages of the disease (Górska et al. 2019). Bacteria in the GI tract metabolize certain dietary components, such as dietary fibers, to produce tumor-suppressive metabolites (Bhatt et al. 2017). These metabolites either act locally or enter the systemic circulation to act on distant targets in the host to protect from inflammation and carcinogenesis.

Tryptophan metabolites, released by colonic bacteria, target and activate aryl hydrocarbon receptor and pregnane/ xenobiotic responsive receptor driving anti-inflammatory response and preventing colon carcinogenesis (Bhutia et al. 2017). Gut microbiota is a source of short-chain fatty acids (SCFAs) including acetate, propionate and butyrate that were described to maintain epithelial integrity (Górska et al. 2019). One function of SCFAs is the epigenetic regulation of gene expression via HDAC inhibition. Butyrate and propionate have been known as inhibitors of both class I and class II HDACs (Cousens et al. 1979; Thangaraju et al. 2006). In colon cancer, both butyrate and propionate showed the ability to inhibit proliferation, invasion and migration. They induced apoptosis in lung cancer cells and suppressed proliferation by upregulating p21 (Kim et al. 2019). Butyrate produced by members of Firmicutes phylum induced apoptosis and suppressed in vitro proliferation of colon, lung and prostate cancer cells (Górska et al. 2019; Kim et al. 2019). Butyric acid was shown to suppress the activation of the nuclear transcription factor kappa $\mathrm{B}$, inhibit histone deacetylation and cyclooxygenase (COX) -2 , and control the activity Bcl-2, Bak, caspase-3 and -7 leading to apoptosis in colorectal cancer (Molska and Reguła 2019).

Cadaverine is a bacterial metabolite produced as a product of decarboxylation of lysine catalyzed by lysine decarboxylase (LDC) expressed in the human bacterial microbiome. Treating Balb/c female mice grafted with $4 \mathrm{~T} 1$ breast cancer cells with cadaverine results in smaller primary tumors, less metastasis and lower grade tumors. Carried out through trace amino acid receptors (TAARs), cadaverine treatment of breast cancer cell lines provoked mesenchymal-to-epithelial transition, restrained invasion, and reduced mitochondrial oxidation, which in turn reduced the stemness of breast cancer stem cells (Kovács et al. 2019).

Polysaccharide A produced by the commensal Bacteroides fragilis was shown to suppress the development of colitis-associated colon cancer (Lee et al. 2018). Butanol extract of the probiotic Bifidobacterium adolescentis SPM0212 exhibited an anti-proliferative effect on Caco2, HT-29 and SW480 colon cancer cells and activated RAW264.7 macrophages by inducing TNF- $\alpha$ and nitric oxide expression (Lee et al. 2008). Lactic acid bacteria have proved advantageous effects in colorectal cancer (CRC) by eliminating carcinogens, synthesizing anti-tumorigenic and anti-mutagenic metabolites, and strengthening the host immunity (An et al. 2019). For example, p8, a protein derived from Lactobacillus rhamnosus (LR), halts the cell cycle progression in CRC cells by downregulating the expression of cyclin B1 and Cdk1 (An et al. 2019). On the 
other hand, the biotransformation of cranberry proanthocyanidins by this bacterium resulted in higher cytotoxicity against HepG2 hepatocellular cell line compared to the parent extract, by Apaf-1 activation and mitochondria-dependent apoptotic mechanism via ATP depletion (Rupasinghe et al. 2019). Moreover, metabolites derived from Lactobacillus plantarum (LDMs) sensitized 5-FU-resistant HCT-116 cells to chemotherapy through downregulating the expression of claudin-1 (CLDN-1), a tight junction transmembrane protein (An \& Ha, 2020). Baicalein, a byproduct of the transformation of an anti-inflammatory component of herb Scutellaria baicalensis by the intestinal microbiota, inhibited gut inflammation by reducing the levels of inflammatory cytokines (IL-2, IL-6) and induced cellular death of cancer cells (Wang et al. 2020).

Ellagic acid, a component of pomegranates, berries, and nuts can be transformed into urolithin A by enteric gut bacteria (García-Mantrana et al. 2019). Urolithin A can halt the expression and activity of Ras-related C3 botulinum toxin substrate 1 (Rac1) and 21 protein-activated kinase 1 (PAK1), thus modulating cellular cytoskeleton by inducing the depolymerization of actin filaments and inhibiting proliferation and migration of cancer cells (Alauddin et al. 2020). Moreover, urolithin A showed the ability to stabilize p53 and upregulate p21 thus inhibiting proliferation and causing G2/M arrest in colon cancer cells. The anti-proliferative effect of urolithin A is also mediated by TIGAR, a p53-dependent glycolytic inhibitor that results in low ATP production and limited cellular growth of colon cancer cells (Norden and Heiss 2019). Urolithin A exerts an anti-cancer activity via the downregulation of both wnt and IGF-1 signaling pathways in colon and pancreatic cancers. It downregulates components of PI3K/AKT/mTOR signaling pathway, decreases the infiltration of immunosuppressive cells such as Tregs and induces apoptosis in pancreatic cancer (Totiger et al. 2019).

\section{Immunomodulatory activity of bacterial extracts}

Immune system deregulations entail many diseases including inflammatory diseases, allergies, autoimmune and infectious diseases (Matsushita and Kawaguchi 2018). Several bacterial extracts have been shown to modulate the immune system to fight such diseases and alleviate their symptoms.

\section{Inflammatory diseases}

Inflammation is a normal and healthy response to stimuli such as injury, pathogens, damaged cells and irritants. In some cases, the immune system attacks the body's own cells or tissues and results in abnormal inflammation, which leads to chronic pain, redness, swelling, stiffness, and damage to normal tissues. Activated immune cells play a significant role in the pathogenesis of many inflammatory diseases (Chen et al. 2018a, b, c). Chronic inflammatory diseases contribute to $50 \%$ of all deaths worldwide being attributable to diseases such as cancer, diabetes mellitus, chronic kidney disease, ischemic heart disease, stroke, non-alcoholic fatty liver disease, and autoimmune and neurodegenerative conditions (Gregory et al. 2018). Several studies have been conducted to find alternative anti-inflammatory immunomodulators to regulate the function and activation of the adaptive and innate immune response. N11, a secondary metabolite from marine microorganisms Pseudomonas sp. was shown to possess anti-inflammatory properties mediated by multiple mechanisms including inhibition of intracellular calcium level and reduction in phosphorylation of p38 MAPK and JNK in human neutrophils (Yang et al. 2014). In fact, inhibitors of the p38 MAPK pathway prevent the progression of collagen-induced arthritis, inflammatory bowel disease and chronic obstructive pulmonary disease (Lomas et al. 2012).

Necrotizing enterocolitis (NEC) is an inflammatory disease that affects premature infants and is characterized by necrosis of the distal small intestine and colon (Meyer et al. 2020). Short-chain fatty acids produced by Bifidobacterium infantis demonstrated anti-inflammatory activities in mature enterocytes and immunocytes (Zheng et al. 2020) which suggests the symbiotic action of breast milk and probiotics in preventing necrotizing enterocolitis (Repa et al. 2015). SCFAs (acetate, propionate and butyrate) were antiinflammatory in a fetal cell line in a mouse intestine after an inflammatory stimulus with IL-1 $\beta$. Their mechanism of action involved the G-protein coupled receptor (GPR 109A) and the inhibition of histone deacetylase 4 and 5 (Zheng et al. 2020). Seven peptides isolated from Faecalibacterium prausnitzii supernatant were found to inhibit NF- $\kappa \mathrm{B}$ pathway in vitro and showed anti-inflammatory properties in vivo in a dinitrobenzene sulfate-induced colitis model (Breyner et al. 2017).

ADR-159, composed of heat-treated fermentates of Lactobacillus fermentum and Lactobacillus delbrueckii along with the microbial biomass generated by them, has been shown to have a therapeutic effect on inflammation induced by $117 r$ (Warda et al. 2019). ADR-159 diet in murine models reduced Citrobacter-induced inflammatory damage without preventing Citrobacter rodentium infection in female mice (Warda et al. 2020). This effect was accompanied by an increase in the expression of IL-12 subunit beta, IFN- $\gamma$, and IL-22 (Jeffrey et al. 2018). Lactobacillus rhamnosus and Lactobacillus helveticus have also been shown to secrete bioactive molecules possessing immunomodulatory activity. They modulate host intestinal epithelial cells response to innate immune stimulants through the secretion of bioactive molecules. These bioactive molecules are able to 
down-regulate IL-8 production by human intestinal epithelial cells (IECs) induced by various innate immune stimuli (Jeffrey et al. 2018).

It is significant to note that some ether extracts of the metabolites of $\beta$-streptococcus, Staphylococcus albus, Staphylococcus aureus, Salmonella enterica serovar Typhi, Salmonella enterica serovar Paratyphi, Escherichia coli, Haemophilus influenza, Moraxella cattarhalis and Diptheroid bacilli showed pro-inflammatory properties. They contain different collagenases which when purified, can stimulate the production of pro-inflammatory cytokines TNF- $\alpha$ and IFN- $\gamma$ in-vitro and in-vivo without inducing noticeable stress and toxicity (Singh and Bhattacharyya 2014).

\section{Allergies and autoimmune diseases}

An allergy is an immune system response to a foreign substance that does not usually cause any harm to the body. Allergy symptoms can range from mild tolerable reactions to a serious life-threatening anaphylaxis (Eller et al. 2018). Allergic rhinitis and asthma are chronic and reversible allergic airway diseases considered significant global public health concerns (Cho et al. 2014). Broncho-Vaxom (OM-85 $\mathrm{BV}$ ) is an extract from Haemophilus influenzae, Diplococcus pneumoniae, Klebsiella pneumonia, Klebsiella ozaenae, S. aureus, Streptococcus pyogenes, Streptococcus viridans and Neisseria catarrhalis responsible for respiratory infections (Bitar and Saade 2013). A study showed that shortand long-term pretreatment with OM- $85 \mathrm{BV}$ leads to the protection from the majority of allergy-specific symptoms in mice. OM-85 BV alleviated nasal symptoms, suppressed eosinophil infiltration in the nose and reduced inflammatory infiltrates. It also reduced the Th2 cytokine response by lowering IL-4, IL-5, IL-13, IgE and IgG1 levels (Han et al. 2014). The level of INF- $\gamma$ was markedly elevated in the OM-85 BV group, which caused a significant reduction in the ratio IL-4/INF- $\gamma$. Thus, OM- 85 BV acts by improving the overall mucosal immunity via the maintenance of an optimal Th1/Th2 cytokine balance (Meng et al. 2019).

A recent study showed that treatment with Helicobacter pylori extracts inhibited inflammatory features in murine models sensitized to allergens that induce allergic airway inflammation. Treatment with the extract decreased allergen-specific IgE and increased IL-10 and IL-17 in cells isolated from the mediastinal lymph node of mice (van Wijck et al. 2019). Moreover, Helicobacter pylori extract has been shown to be a potential therapeutic agent against food allergies. In fact, $H$. pylori extract and its purified immunomodulator VacA conferred detectable protection against anaphylactic symptoms in mice models exposed to ovalbumin and peanut extract. Treatments conferred detectable protection against anaphylactic symptoms of food allergy in the examined models and decreased Th2 cytokine production, mast cell protease secretion, and allergen-specific serum IgG1 levels. The same treatments were shown to affect the epigenome of $\mathrm{T}$ cells, thereby promoting stable Treg differentiation and functionality through the demethylation of the Treg specific demethylated region (TSDR) in FoxP3 + Tregs, promoting their lineage commitment and suppressive activity (Kyburz et al. 2017).

Autoimmune diseases are conditions that are triggered by the immune system attacking healthy cells in the body.

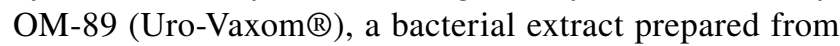
18 uropathogenic Escherichia coli strains, has been shown to modulate immunity in rheumatoid arthritis patients. OM-89 induced a strong production of IL-10, accompanied by a significant decrease in IL-4 production as well as TNF- $\alpha$ and IFN- $\gamma$ (Toussirot et al. 2006). It contains HSP60 and HSP70 and is used for oral administration in the treatment of rheumatoid arthritis models (Nakai, 2016).

\section{Infectious diseases}

Resistance outcomes to anti-infective treatments raised alerts among health authorities to find new antimicrobial treatments like bacterial extracts as alternative drugs for infectious diseases (Esposito 2016). For instance, OM-89 (UroVaxom $($ ) is used to prevent recurrent urinary tract infections (UTI). Typically, it is administered orally as a daily dose for 3 months and is recommended by the European Association of Urology for women with recurrent uncomplicated UTI (Wade et al. 2019). OM-89 acts as an immunostimulator increasing both the innate and adaptive response, and also as an immunoregulator acting on dendritic cells and promoting Treg cells differentiation (Wade et al. 2019). OM-85 BV has been used for nearly 30 years in several countries in both adults and children for the treatment and prevention of recurrent respiratory infections (Triantafillou et al. 2019). This bacterial lysate increases immunoprotection, boosts immunity, reduces the number of respiratory tract infection recurrence and incidence rates in adults and children alike, reduces the intensity of airway-related symptoms, shortens the duration of infection-associated pyrexia, and reduces the number of infections requiring antibiotic treatment (Jurkiewicz and Zielnik-Jurkiewicz 2018). In mice, OM-89 activated macrophages and induced a TH1-type immune response that was observed by increased $\operatorname{IgG} 2 \mathrm{a}$ in the serum and IFN- $\gamma$ in spleen cell supernatant. Moreover, OM-89 increased IL-6 and IFN- $\gamma$ levels and decreased inflammation in the mouse bladder (O'Brien et al. 2016).

For influenza virus, OM-85 BV treatment in mice enhanced both innate and adaptive immunity, led to a dosedependent increase in the surface expression of MHC II, CD40, and CD86 on both CD11b + and CD11b-dendritic cell populations, and enhanced $\mathrm{B}$ cell activation and release of broadly protective antibodies (Pasquali et al. 
2014). OM-85 reduced rhinovirus infection and cell death in lung epithelial cells. It induced an increase in C1q-R and $\beta$-defensin expression important for antigen presentation and phagocytosis, which highlights its modulatory activity on rhinovirus docking proteins on the epithelial cells (Sánchez-Ramón et al. 2018). Acquired immunodeficiency syndrome (AIDS) is a disease of the immune system due to the infection with an enveloped human immunodeficiency virus (HIV). Some studies have focused on the role of the extracellular vesicles (EVs) released by Lactobacillus spp. in preventing HIV-1 transmission. Two Lactobacillus stains, L. gasseri $\mathrm{BC} 12$ and L. crispatus $\mathrm{BC} 3$-derived $\mathrm{EV}$, were found associated with high amounts of metabolites such as methionine, glycine, hypoxanthine, and glutamate. The EVs derived from these strains reduced the infection of MT-4 cells with HIV-1 LAI.04 at the late stage of infection and inhibited the replication of this retrovirus by decreasing the viral entry (Nahui Palomino et al. 2019).

\section{Neuro- and cardioprotective effects of bacterial extracts}

Alzheimer's disease is the most common cause of brain disorders in old adults and it leads to a progressive neurodegeneration of memory and thinking skills. New studies established the neuroprotective effect created by secondary metabolites of marine bacteria (Zhu et al. 2020). Acetylcholinesterase (AChE) inhibitors protect brain cells from neurodegeneration and ROS generation in Alzheimer's disease. Streptomyces sp. UTMC 1334 also known as Streptomyces lateritius was shown to produce pyrroles and other metabolites with AChE inhibitory activity (Almasi et al. 2018). Astrocytes protect the nervous system from oxidative damages caused by ROS generation (Drukarch et al. 1998). Myxobacterial extracts were found to protect the human primary astrocytes from oxidative stress. In fact, pre-treatment of astrocytes with myxobacterial extracts from Archangium sp. UTMC 4070 and Cystobacter sp. UTMC 4073 increased the level of glutathione, an abundant antioxidant molecule in the brain (Dehhaghi et al. 2019).

The relationship between gut microbial metabolism and mental health is one of the most important mechanisms regulating many aspects of host physiology, including immune system maturation and neurodevelopment. This communication has been explored in animal models specifically the bacterivore nematode Caenorhabditis elegans (Sekirov et al. 2010; Valles-Colomer et al. 2019). A recent study has shown that $E$. coli $\mathrm{HT} 115$ strain produces a neuroprotective compound that generates the neurotransmitter $\gamma$-aminobutyric acid (GABA) and thus protects Caenorhabditis elegans neurons from degenerating (Urrutia et al. 2020).
In many pathological conditions, lactic acid bacteria, responsible for the fermentation of milk, are a rich source of metabolites such as peptides that have a cardioprotective effect. Thus, the fermentation of milk with specific strains of Lactococcus lactis has antithrombotic and hypocholesterolemic activities before and after exposure to a simulated gastrointestinal digestion (SGD) model. Two strains of lactic acid bacteria (LAB) Lc-572 and Lc-571 were shown to release bioactive peptides that inhibit thrombine activity before and after gastrointestinal digestion (Rendon-Rosales et al. 2019).

\section{Biological activities of bacterial secondary metabolites}

Bioactive microbial products such as pigments, alkaloids, toxins, antibiotics, gibberellins, carotenoids and biosurfactants, known as secondary metabolites are produced by several bacterial species, fungi and plants, and serve fundamental biological activities such as antibacterial, antifungal, antiviral and antioxidant activities (Table 2).

\section{Antibacterial activity}

Antibiotics are synthesized during the stationary phase of the bacterial division after depletion of one nutrient source such as carbon, nitrogen, or phosphate (Fedorenko et al. 2015). Both gram-positive and gram-negative bacteria have shown resistance to antibacterial therapy, which became the biggest public health challenge of our time. All this led to the discovery of new bioactive molecules secreted by microbial communities in terrestrial niches, endophytes and marine environments (Marinelli et al. 2015).

Positively charged peptides isolated from genus Bacillus were described as antibiotic treatments that can bind to the outer bacterial envelopes, permeabilize the bacterial membranes and translocate into the cytoplasm (Abriouel et al. 2011). Certain strains of Serratia marcescens produce prodigiosin, an antibacterial red pigment (Clements et al. 2019) that exerts an inhibitory effect against gram-positive bacteria S. aureus, Staphylococcus saprophyticus, Enterococcus avium and Streptococcus pyogenes (Darshan and Manonmani 2015) and a bacteriostatic effect on Escherichia coli (Danevcic et al. 2016a, b). Moreover, prodigiosin can cause cell lysis and death in Bacillus subtilis by interacting with the cytoplasmic membrane, increasing the membrane permeability and disrupting the metabolic activity (Danevcic et al. 2016a, b). Serratia marcescens was also shown to produce two classes of biosurfactants, namely lipopeptides and glycolipids. Lipopeptides include three molecular species serrawettin W1, W2, and W3 (Ganley et al. 2018). Serrawettin displayed antimicrobial activity against Pseudomonas aeruginosa, S aureus and Cryptococcus neoformans (Clements 
Table 2 List of microbial-derived natural products with antibacterial, antifungal, antiviral and antioxidant activities

\begin{tabular}{|c|c|c|c|}
\hline Name & Origin & Activity & References \\
\hline Prodigiosin & Serratia marcescens & Antibacterial & $\begin{array}{l}\text { Clements et al. (2019), Danevcic, et al. } \\
\text { (2016a, b), Darshan and Manonmani } \\
(2015)\end{array}$ \\
\hline Serrawettin & Serratia marcescens & & Clements et al. (2019) \\
\hline Germicidins, c-Actinorhodin & Streptomyces lanatus & & Nass et al. (2017); Čihák et al. (2017) \\
\hline Methanolic pigment extract & Micrococcus sp. & & Karbalaei-Heidari et al. (2020) \\
\hline Aminoglycosides (S-137-R) & Bacillus velezensis & & $\begin{array}{l}\text { Kudo and Eguchi (2016), Pournejati et al. } \\
\text { (2019) }\end{array}$ \\
\hline Ethyl acetate extract & $\begin{array}{l}\text { Pseudoalteromonas rubra, Virgibacillus } \\
\text { salaries }\end{array}$ & & Kristiana et al. (2020) \\
\hline Daptomycin & Streptomyces roseospours & & $\begin{array}{l}\text { Canepari et al. (1990), Richter et al. } \\
\text { (2003), Sader et al. (2004) }\end{array}$ \\
\hline Acyl depsipeptide (ADEP) & Streptomyces hawaiiensis & & Goodreid et al. (2014) \\
\hline Lipopeptide lipid 430 & Algibacter sp. M09B557 and M09B04 & & Schneider et al. (2019) \\
\hline $\begin{array}{l}\text { 3-Benzyl-hexahydropyrrolo[1,2-a] } \\
\text { pyrazine-1,4-dione }\end{array}$ & Exiguobacterium indicum SJ16 & & Singh et al. (2019) \\
\hline Juglomycin A & Streptomyces achromogenes E91CS4 & & Ahmad et al. (2020) \\
\hline Kribellosides & Actinobacteria, Kribella MI481-42F6 & Antifungal & Igarashi et al. (2017) \\
\hline Mohangamides A and B & Streptomyces sp. SNM55 & & Bae et al. (2015) \\
\hline Iturine A & Bacillus amyloliquefaciens & & Dang et al. (2019) \\
\hline Methanolic extract & S. aureus & & Hameed (2016) \\
\hline Antimycin A & Streptomyces kaviengensis & Antiviral & Raveh et al. (2013) \\
\hline Xiamycins D & Streptomyces sp. \#HK18 & & Kim et al. (2016) \\
\hline $\begin{array}{l}4862 \mathrm{~F} \\
\text { Ahmpatinin iBu }\end{array}$ & $\begin{array}{l}\text { Streptomyces albosporus I03A-04862 and } \\
\text { Streptomyces sp. CPCC } 202,950\end{array}$ & & Chen et al. (2018a, b, c), Liu et al. (2012) \\
\hline Nostoflan & Nostoc flagelliforme & & Kanekiyo et al. (2007) \\
\hline Thiangazole, phenalamide A1, phenoxan & $\begin{array}{l}\text { Polyangium sp. and Myxococcus stipita- } \\
\text { tus strain }\end{array}$ & & Jurkiewicz et al. (1992) \\
\hline Ratjadon A & Sorangium cellulosum & & Fleta-Soriano et al. (2014) \\
\hline Valinomycin & Streptomyces tsusimaensis & & Cheng (2006), Midhun and Jyothis 2021) \\
\hline Glutathione, Butyrate, Folate & $\begin{array}{l}\text { Bifidobacteria, Lactobacillus fermentum } \\
\text { E-3 and E-18, Clostridium butyricum } \\
\text { MIYAIRI } 588\end{array}$ & Antioxidant & Wang et al. (2017) \\
\hline Intracellular Glutathione & $\begin{array}{l}\text { Streptococcus thermophilus YIT } 2001 \\
\quad \text { (ST-1) }\end{array}$ & & Kusuhara et al. (2018) \\
\hline
\end{tabular}

et al. 2019). Another lipopeptide, Daptomycin, derived as a fermentation product from Streptomyces roseosporus has an excellent bactericidal activity against vancomycinresistant enterococci, coagulase-negative staphylococci, penicillin-resistant Streptococcus pneumoniae (Sader et al. 2004), methicillin-resistant and glycopeptide-intermediate $S$. aureus (Richter et al. 2003). Cell fractionation experiments revealed that daptomycin binds to cell walls and blocks different enzymes or inhibits the synthesis of cell wall macromolecules leading to the permeabilization of the bacterial membrane (Canepari et al. 1990).

Gram-positive bacteria such as Actinomycetes extracted from marine Erylus spp. sponges produce important bioactive metabolites. Microbacterium sp. Berg02-79 showed antibacterial activity against the methicillin-resistant S. aureus (Santos et al. 2019). Germicidins and c-actinorhodin isolated from Streptomyces lanatus have a selective bactericidal effect on Bacillus subtilis and S. aureus (Nass et al. 2017; Čihák et al. 2017). A methanolic pigment extract from Micrococcus sp. MP76 was described to inhibit the growth of $S$. aureus, $P$. aeruginosa and $E$. coli (Karbalaei-Heidari et al. 2020). Aminoglycosides produced by the Bacillus velezensis strain RP137 were found to target bacterial ribosomes including the inhibition of protein synthesis and S-137-R had a moderate antibacterial effect on S. aureus and P. aeruginosa (Kudo and Eguchi 2016; Pournejati et al. 2019). Moreover, a study has shown that the ethyl acetate extracts of the supernatant of Pseudoalteromonas rubra and Virgibacillus salaries inhibit 
the growth of resistant $S$. aureus (Kristiana et al. 2020). Acyl depsipeptide antibiotics derived from Streptomyces hawaiiensis protect against resistant Streptococcus pneumoniae, S. aureus and Enterococcus faecalis bacteria by binding to ceramide-1-phosphate phosphatase $(\mathrm{C} 1 \mathrm{pP})$ and causing the degradation of cell division-specific proteins (Goodreid et al. 2014).

Two bacterial strains belonging to the genus Algibacter, M09B557 isolated from Alcyonidium gelatinosum and M09B04 isolated from a soft coral, were described to inhibit the growth of Streptococcus agalactiae by secreting lipid 430, a bioactive lipopeptide (Schneider et al. 2019). Gram-positive and gram-negative bacteria use cell-to-cell communication systems such as quorum sensing circuits to regulate gene expression in response to cell density. $\mathrm{N}$-acyl-homoserine lactones are a class of signaling molecules involved in bacterial quorum sensing. Rhodococcus erythropolis strain R138 showed an antivirulence effect against the human pathogen $P$. aeruginosa PA14 by catabolizing N-acyl-homoserine lactones (Barbey et al. 2018). Moreover, a study has shown that Bacillus sp. QSI-1 disrupts the virulence of A. hydrophila YJ-1 by decreasing significantly the expression of virulence factors such as hemolysin, protease and N-Acyl homoserine lactones (Zhou et al. 2019). Additional studies have demonstrated that the active compound 3-Benzyl-hexahydropyrrolo[1,2-a]pyrazine-1,4-dione extracted from Exiguobacterium indicum SJ16 inhibits the biofilm formation of two P. aeruginosa strains, PAO1 and PAH by decreasing their motility and the production of virulence factors, and quorum sensing regulatory mediators such as pyocyanin, rhamnolipid, elastase and protease (Singh et al. 2019).

Endophytes are rich sources of bioactive compounds and secondary metabolites used as antibacterial agents (Afzal et al. 2019). Pseudomonas sp. crude extract isolated from Crinum macowanii Baker inhibits the growth of Bacillus cereus, Staphylococcus epidermidis, and Mycobacterium marinum (Sebola et al. 2019a). Endophytes Pantoea eucalypti, Pantoea vagans and Pantoea ananatis isolated from Solanum mauritianum have an antibacterial activity against $S$. aureus, Bacillus cereus, Staphylococcus epidermidis and Bacillus subtilis (Uche-Okereafor et al. 2019). A recent study showed that the biological compound Juglomycin A produced by Streptomyces achromogenes E91CS4, an endophyte of $C$. sativus, reduces the biofilm formation in Escherichia coli by inhibiting its motility and down-regulating its adhesion mediator fimH gene. Juglomycin A also inhibits the growth of several bacteria such as Shigella dysenteriae, Pseudomonas fluorescens, Streptococcus pyogenes, S. aureus, Staphylococcus warneri, Clostridium pasteurianum and Candida albicans (Ahmad et al. 2020).

\section{Antifungal activity}

The need for antifungal secondary metabolites increased with the expanding number of fungal infections (De Lucca and Walsh 1999). Actinobacteria Kribella MI481-42F6 was shown to produce kribellosides that inhibit the activity of RNA 5'-triphosphatase in Saccharomyces cerevisiae (Igarashi et al. 2017). Mohangamides A and B, purified from Streptomyces sp. SNM55, inhibited the growth of Candida albicans by decreasing the expression of its isocitrate lyase (Bae et al. 2015). Moreover, it was recently shown that Bacillus velezensis DTU001 reduces the growth of $C$. albicans under planktonic conditions and during biofilm development (Devi et al. 2019). Further reports are required to define the role of iturin, an amphiphilic antifungal metabolite, composed from a peptide and a fatty acyl moiety (Chae Gun et al. 1990; Verschuere et al. 2000). These compounds form a cyclic structure through the linkage of the hydrophobic long alkyl chain to a hydrophilic polypeptide which has the ability to accumulate between fluid phases reducing surface and interfacial tension. Consequently, this moiety leads to the deformation of the rough cell surface and the cytoplasmic material leakage of the bacterial cell (Rautela et al. 2014).

Among the gene clusters, the operons itu $\mathrm{D}$, itu A, itu $\mathrm{B}$ and itu $\mathrm{C}$ are responsible for iturin $\mathrm{A}$ biosynthesis. The strong constitutive promoter C2up enhances the transcription of the itu operons. The substitution of $\mathrm{C} 2$ up for the native iturin synthetase promoter enhanced the production of Iturine A by B. amyloliquefaciens LL3. Currently, more efforts are still needed for the elucidation of the industrial production of iturin A by the strain (Dang et al. 2019). Iturine A produced by Bacillus amyloliquefaciens C2LP inhibited the growth of Alternaria alternate, Botrytis cinerea, Colletotrichum gloeosporioides, Fusariumoxysporum and Rhizoctoniasolani (Dang et al. 2019). Furthermore, previous studies showed that thirty-five bioactive chemical constituents identified in the methanolic extract of $S$. aureus suppress the growth of Aspergillus terreus (Hameed 2016). In addition, the secondary metabolites produced by Pseudomonas stutzeri ST1302 and Klebsiella pneumonia ST250 have a promising effect against 11 strains of fungus-like Pythium insidiosum isolated from human pythiosis in Thailand (Wittayapipath et al. 2020).

\section{Antiviral activity}

Pathogenic viral infections not only cause morbidity and mortality of the host but are also associated with a considerable economic damage necessitating immediate intervention strategies ranging from prevention, treatment discovery and establishment of effective vaccines. Secondary metabolites produced by bacteria hold a great antiviral therapeutic 
potential. Antimycin A1a isolated from Streptomyces kaviengensis disrupted the mitochondrial electron transport and the biosynthesis of pyrimidine in Western Equine Encephalitis virus (WEEV) and its commercial form reduced viral titers in mice infected with WEEV and improved their overall survival (Raveh et al. 2013). Xiamycins D produced by Streptomyces sp. \#HK18 inhibited the expression of structural proteins GP6 nucleocapsid, GP2 spike, and GP5 membrane of porcine epidemic diarrhea virus (PEDV) (Kim et al. 2016). 4862F and Ahmpatinin iBu isolated from Streptomyces albosporus I03A-04862 and Streptomyces sp. CPCC 202,950 respectively, targeted HIV-1 protease which perturbates the life cycle of this virus (Chen et al. 2018a, b, c; Liu et al. 2012). Moreover, thiangazole, phenalamide A1 and phenoxan isolated from two strains of Polyangium $s p$. and Myxococcus stipitatus strain Mx s40 inhibited HIV-1 reverse transcriptase activity and prevented cell death in virus-infected MT-4 cells (Jurkiewicz et al. 1992). Another study showed that the Rev/CRM1-mediated nuclear export pathway in HIV virus was blocked by Ratjadon A isolated from Sorangium cellulosum (Fleta-Soriano et al. 2014). Nostoflan produced by Nostoc flagelliforme restrained the binding of enveloped viruses such as HSV, HCMV, and influenza A virus to the host cells (Kanekiyo et al. 2007). Interestingly, valinomycin extracted from the endophytes Streptomyces tsusimaensis was studied for its antiviral activity against coronaviruses such as SARS-CoV, MERS-CoV, and human coronavirus OC43 (HCoV-OC43), which highlights its future potential use as an antiviral agent against SARSCoV-2 (Cheng 2006; Midhun and Jyothis 2021).

\section{Antioxidant activity}

Reactive oxygen species (ROS) including superoxide anion radicals, hydroxyl radicals and hydrogen peroxide trigger an oxidative stress that leads to many human diseases such as diabetes, atherosclerosis, Alzheimer's disease and cancer (Lobo et al. 2010). Probiotics that contain enzymes like superoxide dismutase, glutathione peroxidase and glutathione reductase as well as antioxidants such as glutathione, thioredoxin, vitamins $\mathrm{C}$ and $\mathrm{E}$, help reducing damages caused by oxidation (Stecchini et al. 2001). Glutathione, butyrate, and folate from Bifidobacteria, Lactobacillus fermentum E-3 and E-18 and Clostridium butyricum MIYAIRI 588 demonstrated an antioxidant effect (Wang et al. 2017).

Moreover, Lactobacillus plantarum, Alteromonas australica, Bacillus niacini, Lysinibacillus fusiformis and Vibrio harveyi produce bioactive compounds that exhibit antioxidant activity (Baker et al. 2019). AR2 crude extract from Streptomyces lanatus attenuates oxidative stress (Riahi et al. 2019) and 18 Streptomyces strains isolated from rhizosphere soils exhibit significant antioxidant activity (Law et al.
2019). A lactic acid bacterial strain, Streptococcus thermophilus YIT 2001 (ST-1), was found to contain intracellular glutathione that provides an antioxidant activity against lowdensity oxidation (Kusuhara et al. 2018).

\section{Conclusion}

The discovery of natural remedies is expanding through the efforts done to find alternative therapies using microbial species. Research on microbes has always played an essential role in the improvement of biotechnological and biomedical areas. As discussed in this review, bacteria remain a potent factory for natural products with vast therapeutic effectiveness. The important biological functions of these products along with their anti-cancer mechanisms of action are illustrated in Fig. 1. Bacterial secondary metabolites continue to broaden their diverse and integral role in modern medicine and their involvement in human health still expects further global work and research.

Combination of secondary metabolites with chemotherapies is one of the most promising pathways in the battle against cancer. Several clinical trials are conducted to find therapeutic candidates. For instance, in a phase II study on 49 cervical cancer patients, the treatment with a combination of ifosfamide, bleomycin, and cisplatin (BIP) for a median duration of 8 months showed that $69 \%$ of patients presented an objective response while $20 \%$ showed a complete response (Buxton et al. 1989). $75 \%$ of patients treated with BIP followed by radiotherapy showed a complete response compared to $56 \%$ with radiotherapy only (Tobias et al. 1990). Epigenetic regulation through HDAC inhibitors (HDACi) is a widely studied anti-cancer mechanism. HDACi romidepsin isolated from Chromobacterium violaceum was found to inhibit the growth of T cell lymphoma in phase I and II clinical trials (Nakajima et al. 1998). 35\% of patients with cutaneous $\mathrm{T}$ cell lymphoma (CTCL) responded to romidepsin after durations of 11.1 months (Piekarz et al. 2009). However, phase I/ II trials showed concerns about few side effects such as a reduction in the number of blood cells (Maruyama et al. 2017). Future phase II trial using Romidepsin after Gemcitabine, Dexamethasone, and Cisplatin will be tested in Japan against peripheral $\mathrm{T}$ cell lymphoma with short-term effects (Yamasaki et al. 2019). Since 2003, the first geldanamycin derivative 17-AAG (17-N-allylamino17-dimethoxygeldanamycin) has been used in a total of 35 phase I clinical trials in cancer patients. Despite its pharmacological potency, 17-AAG showed low water solubility and high hepatotoxicity that restricted its clinical use and $23 \%$ of the phase I trials were not progressed past phase II (Sanchez et al. 2020). Nowadays, the use of advanced technology and nanomaterials-based drug delivery carriers and the understanding of the mechanisms of 


\section{Legend}

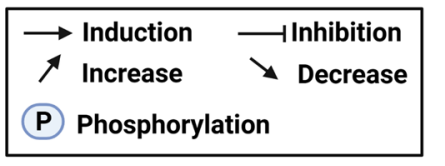

1. Metabolic modulation

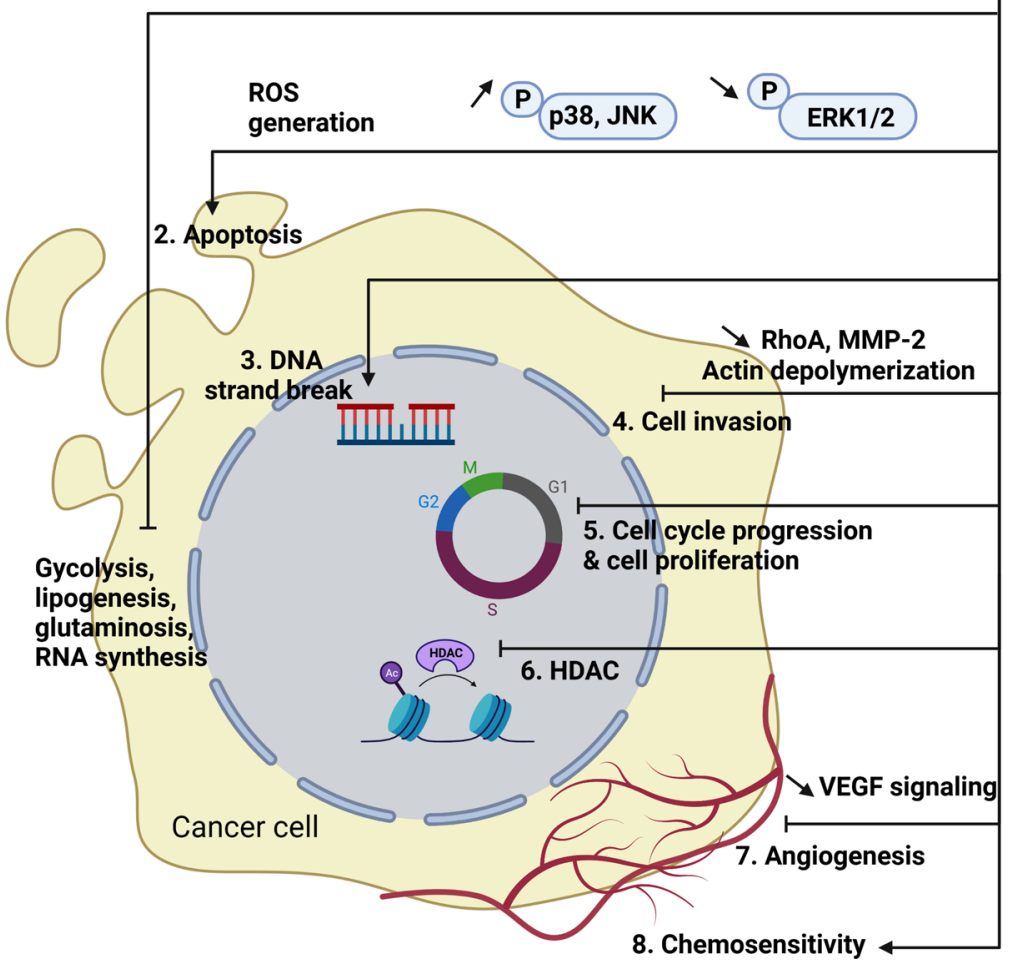

\section{Bacterial isolate}

Anticancer activity

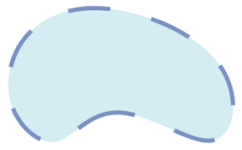

Immunomodulatory activity

Alleviation of inflammation, allergy and autoimmune diseases

\section{Cardioprotective activity}

\section{Neuroprotective activity}

\section{Antimicrobial activity}

Antiviral, antibacterial, antifungal

\section{Antioxidant activity}

Fig. 1 Biological activities and applications of bacterial-derived compounds. Bacterial isolates can modulate the immune system and alleviate inflammation, allergies and autoimmune diseases. They can exert biological activities such as antibacterial, antifungal, antiviral and antioxidant activities, as well as neuro- and cardioprotective effects. Bacterial-derived compounds can have anti-cancer properties and their mechanisms of action include (1) the modulation of the metabolism in cancer cells by inhibiting glycolysis, lipogenesis, glutaminosis and RNA synthesis; (2) the induction of apoptosis via ROS generation, upregulation of phosphorylated p38 mitogen-activated protein kinase (p38 MAPK) and c-Jun N-terminal kinase (JNK),

action of the metabolites will allow more controlled and efficient clinical trials. An ongoing phase III trial is evaluating the efficacy and safety of oral Paclitaxel in recurrent and metastatic breast cancer as first-line therapy. A clinical study was launched to evaluate the role of OM-85 BV on children with Wheezing Lower Respiratory Tract Illness (WLRI) and is expected to be completed in 2025. Thus, as discussed, whether in clinical testing, FDA approval or the mechanisms behind their therapeutic activity, the applications of bacterial secondary metabolites and extracts still hold vast openings for exploration and investigation. and downregulation of phosphorylated extracellular signal-regulated kinase (ERK1/2); (3) the induction of DNA strand break; (4) the inhibition of cancer cell invasion by downregulating Ras homolog family member A (RhoA) and matrix metalloproteinase (MMP) and inducing actin depolymerization; (5) the inhibition of cell proliferation and progression through the cell cycle; (6) the inhibition of histone deacetylase (HDAC); (7) the inhibition of angiogenesis by downregulating vascular endothelial growth factor (VEGF); (8) the stimulation of chemosensitivity in drug-resistant cancer cells "Created with BioRe nder.com"

Author contributions RHS, MM and GD designed, directed, and coordinated this project. ZA, NH and ZZ made substantial contributions in providing critical feedback and drafting the manuscript. RHS, MM and GD reviewed the final manuscript.

Funding Not applicable.

Code availability Not applicable.

\section{Declarations}

Conflict of interest The authors Zainab Abdelghani, Nancy Hourani, Zahraa Zaidan, Ghassan Dbaibo, Marguerite Mrad and Rouba HageSleiman declare that they have no conflict of interest. 
Ethical approval The work is completely within the professional code of ethics.

Consent to participate All authors consent to participate in this work.

Consent for publication Informed consent was obtained from all individual participants included in the study.

\section{References}

Abdalla MA, Matasyoh JC (2014) Endophytes as producers of peptides: an overview about the recently discovered peptides from endophytic microbes. Nat Prod Bioprospect 4(5):257-270

Abdelnasser SM, Yahya SMM, Mohamed WF, Asker MM, Abu Shady HM, Mahmoud MG, Gadallah MA (2017) Antitumor exopolysaccharides derived from novel marine bacillus: isolation, characterization aspect and biological activity. Asian Pac J Cancer Prev 18(7):1847-1854

Abriouel H, Franz CMAP, Omar NB, Gálvez A (2011) Diversity and applications of Bacillus bacteriocins. FEMS Microbiol Rev 35(1):201-232. https://doi.org/10.1111/j.1574-6976.2010. 00244.x

Aftab U, Zechel DL, Sajid I (2015) Antitumor compounds from Streptomyces sp. KML-2, isolated from Khewra salt mines, Pakistan. Biol Res 48(1):58. https://doi.org/10.1186/s40659-015-0046-3

Afzal I, Shinwari ZK, Sikandar S, Shahzad S (2019) Plant beneficial endophytic bacteria: mechanisms, diversity, host range and genetic determinants. Microbiol Res 221:36-49. https://doi.org/ 10.1016/j.micres.2019.02.001

Ahmad T, Arora P, Nalli Y, Ali A, Riyaz-Ul-Hassan S (2020) Antibacterial potential of Juglomycin A isolated from Streptomyces achromogenes, an endophyte of Crocus sativus Linn. J Appl Microbiol 128(5):1366-1377. https://doi.org/10.1111/jam.14568

Alauddin M, Okumura T, Rajaxavier J, Khozooei S, Pöschel S, Takeda S, Singh Y, Brucker SY, Wallwiener D, Koch A, Salker MS (2020) Gut bacterial metabolite urolithin a decreases actin polymerization and migration in cancer cells. Mol Nutr Food Res 64(7): 17

Alem D, Marizcurrena JJ, Saravia V, Davyt D, Martinez-Lopez W, Castro-Sowinski S (2020) Production and antiproliferative effect of violacein, a purple pigment produced by an Antarctic bacterial isolate. World J Microbiol Biotechnol 36(8):120. https://doi.org/ 10.1007/s11274-020-02893-4

Almasi F, Mohammadipanah F, Adhami HR, Hamedi J (2018) Introduction of marine-derived Streptomyces sp. UTMC 1334 as a source of pyrrole derivatives with anti-acetylcholinesterase activity. J Appl Microbiol 125(5):1370-1382. https://doi.org/10.1111/ jam. 14043

An J, Ha EM (2020) Lactobacillus-derived metabolites enhance the antitumor activity of 5-FU and inhibit metastatic behavior in 5-FU-resistant colorectal cancer cells by regulating claudin-1 expression. J Microbiol 58(11):967-977. https://doi.org/10.1007/ s12275-020-0375-y

An BC, Ryu Y, Yoon YS, Choi O, Park HJ, Kim TY, Kim SI, Kim BK, Chung MJ (2019) Colorectal cancer therapy using a Pediococcus pentosaceus SL4 drug delivery system secreting lactic acid bacteria-derived protein p8. Mol Cells 42(11):755-762

Anas A, Nilayangod C, Jasmin C, Vinothkumar S, Parameswaran PS, Nair S (2016) Diversity and bioactive potentials of culturable heterotrophic bacteria from the surficial sediments of the Arabian Sea. 3 Biotech 6(2):016-0556

Bae M, Kim H, Moon K, Nam SJ, Shin J, Oh KB, Oh DC (2015) Mohangamides A and B, new dilactone-tethered pseudo-dimeric peptides inhibiting Candida albicans isocitrate lyase. Org Lett 17(3):712-715. https://doi.org/10.1021/ol5037248

Bahrami A, Hasanzadeh M, Hassanian SM, ShahidSales S, GhayourMobarhan M, Ferns GA, Avan A (2017) The potential value of the $\mathrm{PI} 3 \mathrm{~K} / \mathrm{Akt} / \mathrm{mTOR}$ signaling pathway for assessing prognosis in cervical cancer and as a target for therapy. J Cell Biochem 118(12):4163-4169. https://doi.org/10.1002/jcb.26118

Baker D, Basondwah S, Jambi E, Rahimuddin S, Abuzaid M, Aly M (2019) Molecular identification, characterization and antioxidant activities of some bacteria associated with algae in the Red Sea of Jeddah. Pak J Biol Sci 22:467-476. https://doi.org/ 10.3923/pjbs.2019.467.476

Balachandran C, Sangeetha B, Duraipandiyan V, Raj MK, Ignacimuthu S, Al-Dhabi NA, Balakrishna K, Parthasarathy K, Arulmozhi NM, Arasu MV (2014) A flavonoid isolated from Streptomyces sp. (ERINLG-4) induces apoptosis in human lung cancer A549 cells through p53 and cytochrome c release caspase dependant pathway. Chem Biol Interact 224:24-35

Barbey C, Chane A, Burini JF, Maillot O, Merieau A, Gallique M, Beury-Cirou A, Konto-Ghiorghi Y, Feuilloley M, Gobert V, Latour X (2018) A rhodococcal transcriptional regulatory mechanism detects the common lactone ring of AHL quorumsensing signals and triggers the quorum-quenching response. Front Microbiol 9:2800. https://doi.org/10.3389/fmicb.2018. 02800

Bhatt AP, Redinbo MR, Bultman SJ (2017) The role of the microbiome in cancer development and therapy. CA Cancer J Clin 67(4):326-344

Bhutia YD, Ogura J, Sivaprakasam S, Ganapathy V (2017) Gut microbiome and colon cancer: role of bacterial metabolites and their molecular targets in the host. Curr Colorectal Cancer Rep 13(2):111-118

Bi YL, Mi PY, Zhao SJ, Pan HM, Li HJ, Liu F, Shao LR, Zhang HF, Zhang P, Jiang SL (2017) Salinomycin exhibits anti-angiogenic activity against human glioma in vitro and in vivo by suppressing the VEGF-VEGFR2-AKT/FAK signaling axis. Int J Mol Med 39(5):1255-1261

Bitar MA, Saade R (2013) The role of OM-85 BV (Broncho-Vaxom) in preventing recurrent acute tonsillitis in children. Int $\mathrm{J}$ Pediatr Otorhinolaryngol 77(5):670-673. https://doi.org/10.1016/j.ijporl. 2013.01.009

Brasseur K, Auger P, Asselin E, Parent S, Côté JC, Sirois M (2015) Parasporin-2 from a new Bacillus thuringiensis 4R2 strain induces caspases activation and apoptosis in human cancer cells. PLoS ONE 10(8):e0135106

Breyner NM, Michon C, de Sousa CS, Vilas Boas PB, Chain F, Azevedo VA, Langella P, Chatel JM (2017) Microbial antiinflammatory molecule (MAM) from. Front Microbiol 8:114. https://doi.org/10.3389/fmicb.2017.00114

Buxton EJ, Meanwell CA, Hilton C, Mould JJ, Spooner D, Chetiyawardana A, Latief T, Paterson M, Redman CW, Luesley DM, \&, et al (1989) Combination bleomycin, ifosfamide, and cisplatin chemotherapy in cervical cancer. J Natl Cancer Inst 81(5):359361. https://doi.org/10.1093/jnci/81.5.359

Canepari P, Boaretti M, Lleo M, Satta G (1990) Lipoteichoic acid as a new target for activity of antibiotics: mode of action of daptomycin (LY146032). Antimicrob Agents Chemother 34:1220-1226. https://doi.org/10.1128/AAC.34.6.1220

Chae Gun P, Shoda M, Kubota H (1990) Suppressive effect of Bacillus subtilis and it's products on phytopathogenic microorganisms. J Ferment Bioeng 69(1):1-7. https://doi.org/10.1016/j.jbiosc. 2010.12.026

Chang CC, Chen WC, Ho TF, Wu HS, Wei YH (2011) Development of natural anti-tumor drugs by microorganisms. J Biosci Bioeng 111(5):501-511 
Chen X, Li M, Li L, Xu S, Huang D, Ju M, Huang J, Chen K, Gu H (2016) Trehalose, sucrose and raffinose are novel activators of autophagy in human keratinocytes through an mTOR-independent pathway. Sci Rep 6:28423. https://doi.org/10.1038/srep28423

Chen L, Deng H, Cui H, Fang J, Zuo Z, Deng J, Li Y, Wang X, Zhao L (2018a) Inflammatory responses and inflammation-associated diseases in organs. Oncotarget 9(6):7204-7218. https://doi.org/ 10.18632/oncotarget.23208

Chen M, Chai W, Song T, Ma M, Lian X-Y, Zhang Z (2018b) Anti-glioma natural products downregulating tumor glycolytic enzymes from marine actinomycete Streptomyces sp. ZZ406. Sci Rep 8(1):72. https://doi.org/10.1038/s41598-017-18484-7

Chen M-H, Chang S-S, Dong B, Yu L-Y, Wu Y-X, Wang R-Z, Jiang W, Gao Z-P, Si S-Y (2018c) Ahmpatinin iBu, a new HIV-1 protease inhibitor, from Streptomyces sp. CPCC 202950. RSC Adv 8(10):5138-5144. https://doi.org/10.1039/C7RA13241G

Cheng YQ (2006) Deciphering the biosynthetic codes for the potent anti-SARS-CoV cyclodepsipeptide valinomycin in Streptomyces tsusimaensis ATCC 15141. ChemBioChem 7(3):471-477. https://doi.org/10.1002/cbic.200500425

Chin YW, Balunas MJ, Chai HB, Kinghorn AD (2006) Drug discovery from natural sources. AAPS J 8(2):E239-253. https://doi.org/10. 1007/BF02854894

Cho KS, Park MK, Kang SA, Park HY, Hong SL, Park HK, Yu HS, Roh HJ (2014) Adipose-derived stem cells ameliorate allergic airway inflammation by inducing regulatory $\mathrm{T}$ cells in a mouse model of asthma. Mediators Inflamm 2014:436476. https://doi. org/10.1155/2014/436476

Choi H, Oh DC (2015) Considerations of the chemical biology of microbial natural products provide an effective drug discovery strategy. Arch Pharm Res 38(9):1591-1605. https://doi.org/10. 1007/s12272-015-0639-y

Čihák M, Kameník Z, Šmídová K, Bergman N, Benada O, Kofroňová O, Petříčková K, Bobek J (2017) Secondary metabolites produced during the germination of Streptomyces coelicolor. Front Microbiol 8:2495. https://doi.org/10.3389/fmicb.2017.02495

Clements T, Ndlovu T, Khan W (2019) Broad-spectrum antimicrobial activity of secondary metabolites produced by Serratia marcescens strains. Microbiol Res 229:126329. https://doi.org/10. 1016/j.micres.2019.126329

Coleman OI, Haller D (2018) Bacterial signaling at the intestinal epithelial interface in inflammation and cancer. Front Immunol 8:1927

Cousens LS, Gallwitz D, Alberts BM (1979) Different accessibilities in chromatin to histone acetylase. J Biol Chem 254(5):1716-1723

Cragg GM, Grothaus PG, Newman DJ (2009) Impact of natural products on developing new anti-cancer agents. Chem Rev 109(7):3012-3043. https://doi.org/10.1021/cr900019j

Dan VM, Muralikrishnan B, Sanawar R, Vinodh JS, Burkul BB, Srinivas KP, Lekshmi A, Pradeep NS, Dastager SG, Santhakumari B, Santhoshkumar TR, Kumar RA, Pillai MR (2018) Streptomyces sp. metabolite(s) promotes Bax mediated intrinsic apoptosis and autophagy involving inhibition of mTOR pathway in cervical cancer cell lines. Sci Rep 8(1):018-21249

Danevcic T, Boric Vezjak M, Tabor M, Zorec M, Stopar D (2016a) Prodigiosin induces autolysins in actively grown Bacillus subtilis cells. Front Microbiol 7:27. https://doi.org/10.3389/fmicb. 2016.00027

Danevcic T, Boric Vezjak M, Zorec M, Stopar D (2016b) Prodigiosin: a multifaceted Escherichia coli antimicrobial agent. PLoS ONE 11(9):e0162412. https://doi.org/10.1371/journal.pone.0162412

Dang Y, Zhao F, Liu X, Fan X, Huang R, Gao W, Wang S, Yang C (2019) Enhanced production of antifungal lipopeptide iturin A by Bacillus amyloliquefaciens LL3 through metabolic engineering and culture conditions optimization. Microb Cell Fact 18(1):68. https://doi.org/10.1186/s12934-019-1121-1
Darshan N, Manonmani HK (2015) Prodigiosin and its potential applications. J Food Sci Technol 52(9):5393-5407. https://doi.org/10. 1007/s13197-015-1740-4

De Lucca AJ, Walsh TJ (1999) Antifungal peptides: novel therapeutic compounds against emerging pathogens. Antimicrob Agents Chemother 43(1):1-11

Dehhaghi M, Tan V, Heng B, Mohammadipanah F, Guillemin GJ (2019) Protective effects of myxobacterial extracts on hydrogen peroxide-induced toxicity on human primary astrocytes. Neuroscience 399:1-11. https://doi.org/10.1016/j.neuroscience.2018. 11.033

Demain AL, Vaishnav P (2011) Natural products for cancer chemotherapy. Microb Biotechnol 4(6):687-699. https://doi.org/10. 1111/j.1751-7915.2010.00221.x

Devi S, Kiesewalter HT, Kovacs R, Frisvad JC, Weber T, Larsen TO, Kovacs AT, Ding L (2019) Depiction of secondary metabolites and antifungal activity of Bacillus velezensis DTU001. Synth Syst Biotechnol 4(3):142-149. https://doi.org/10.1016/j.synbio. 2019.08.002

Dey G, Bharti R, Dhanarajan G, Das S, Dey KK, Kumar BN, Sen R, Mandal M (2015) Marine lipopeptide iturin A inhibits Akt mediated GSK3 $\beta$ and FoxO3a signaling and triggers apoptosis in breast cancer. Sci Rep 5:10316

Dhaneesha M, Benjamin Naman C, Krishnan KP, Sinha RK, Jayesh P, Joseph V, Bright Singh IS, Gerwick WH, Sajeevan TP (2017) Streptomyces artemisiae MCCB 248 isolated from Arctic fjord sediments has unique PKS and NRPS biosynthetic genes and produces potential new anticancer natural products. 3 Biotech 7(1):0170610

Di Marco A, Cassinelli G, Arcamone F (1981) The discovery of daunorubicin. Cancer Treat Rep 65(Suppl 4):3-8

Dimasi P, Quintiero A, Shelkovnikova T, Buchman V (2017) Modulation of p-eIF $2 \alpha$ cellular levels and stress granule assembly/ disassembly by trehalose. Sci Rep 7:44088. https://doi.org/10. 1038/srep44088

Donnelly A, Blagg BS (2008) Novobiocin and additional inhibitors of the Hsp90 C-terminal nucleotide-binding pocket. Curr Med Chem 15(26):2702-2717

Drukarch B, Schepens E, Stoof JC, Langeveld CH, Van Muiswinkel FL (1998) Astrocyte-enhanced neuronal survival is mediated by scavenging of extracellular reactive oxygen species. Free Radic Biol Med 25(2):217-220. https://doi.org/10.1016/s08915849(98)00050-1

Dube PN, Sakle NS, Dhawale SA, More SA, Mokale SN (2019) Synthesis, biological investigation and docking study of novel chromen derivatives as anti-cancer agents. Anticancer Agents Med Chem 19(9):1150-1160. https://doi.org/10.2174/18715 20619666190307121145

Ek-Ramos MJ, Gomez-Flores R, Orozco-Flores AA, Rodríguez-Padilla C, González-Ochoa G, Tamez-Guerra P (2019) Bioactive products from plant-endophytic gram-positive bacteria. Front Microbiol 10:463

Elahian F, Moghimi B, Dinmohammadi F, Ghamghami M, Hamidi M, Mirzaei SA (2013) The anticancer agent prodigiosin is not a multidrug resistance protein substrate. DNA Cell Biol 32(3):90-97

Eller E, Muraro A, Dahl R, Mortz CG, Bindslev-Jensen C (2018) Assessing severity of anaphylaxis: a data-driven comparison of 23 instruments. Clin Transl Allergy 8:29. https://doi.org/10.1186/ s13601-018-0215-x

Erba E, Bergamaschi D, Ronzoni S, Faretta M, Taverna S, Bonfanti M, Catapano CV, Faircloth G, Jimeno J, D'Incalci M (1999) Mode of action of thiocoraline, a natural marine compound with antitumour activity. Br J Cancer 80(7):971-980. https://doi.org/10. 1038/sj.bjc.6690451 
Esposito S (2016) Infectious diseases: pathophysiology, diagnostics and prevention. Int J Mol Sci. https://doi.org/10.3390/ijms1 7091464

Faramarzian AMB, Fatourachi P, Mohammadi SM, Valipour B, Behtari M, Dehnad A, Nozad CH (2018) Streptomyces Levis ABRIINW111 Inhibits SW480 Cells Growth by Apoptosis Induction. Adv Pharm Bull 8(4):675-682. https://doi.org/10.15171/apb. 2018.076

Fatourachi P, Faramarziyan AMB, Mohammadi SM, Valipour B, Dehnad A, Nozad CH (2018) Extracted metabolite from Streptomyces Levis ABRIINW111 altered the gene expression in colon cancer. Gastroenterol Hepatol Bed Bench 11(1):34-41

Fedorenko V, Genilloud O, Horbal L, Marcone GL, Marinelli F, Paitan Y, Ron EZ (2015) Antibacterial discovery and development: from gene to product and back. Biomed Res Int 2015:591349. https://doi.org/10.1155/2015/591349

Fleta-Soriano E, Martinez JP, Hinkelmann B, Gerth K, Washausen P, Diez J, Frank R, Sasse F, Meyerhans A (2014) The myxobacterial metabolite ratjadone A inhibits HIV infection by blocking the Rev/CRM1-mediated nuclear export pathway. Microb Cell Fact 13:17-17. https://doi.org/10.1186/1475-2859-13-17

Fu G, Wang R, Ding J, Qi H, Zhao Z, Chen C, Zhang H, Xue Z, Wang J, Wu M (2020) Micromonospora zhangzhouensis sp. nov., a Novel actinobacterium isolated from mangrove soil, exerts a cytotoxic activity in vitro. Sci Rep 10(1):3889. https://doi.org/ 10.1038/s41598-020-60677-0

Furumai R, Matsuyama A, Kobashi N, Lee KH, Nishiyama M, Nakajima H, Tanaka A, Komatsu Y, Nishino N, Yoshida M, Horinouchi S (2002) FK228 (depsipeptide) as a natural prodrug that inhibits class I histone deacetylases. Cancer Res 62(17):4916-4921

Ganley JG, Carr G, Ioerger TR, Sacchettini JC, Clardy J, Derbyshire ER (2018) Discovery of antimicrobial lipodepsipeptides produced by a Serratia sp. within mosquito microbiomes. ChemBioChem 19(15):1590-1594. https://doi.org/10.1002/cbic.20180 0124

García-Mantrana I, Calatayud M, Romo Vaquero M, Espín JC, Selma M, Collado MC (2019) Urolithin metabotypes can determine the modulation of gut microbiota in healthy individuals by tracking walnuts consumption over three days. Nutrients 11:2483. https:// doi.org/10.3390/nu11102483

Gaynes R (2017) The discovery of penicillin—new insights after more than 75 years of clinical use. Emerg Infect Dis 23(5):849-853. https://doi.org/10.3201/eid2305.161556

Goodreid JD, Wong K, Leung E, McCaw SE, Gray-Owen SD, Lough A, Houry WA, Batey RA (2014) Total synthesis and antibacterial testing of the A54556 cyclic acyldepsipeptides isolated from Streptomyces hawaiiensis. J Nat Prod 77(10):2170-2181. https:// doi.org/10.1021/np500158q

Gorska M, Popowska U, Sielicka A, Kuban-Jankowska A, Sawczuk W, Knap N, Cicero G, Wozniak F (2012) Geldanamycin and its derivatives as Hsp90 inhibitors. Front Biosci 17:2269-2277

Górska A, Przystupski D, Niemczura MJ, Kulbacka J (2019) Probiotic bacteria: a promising tool in cancer prevention and therapy. Curr Microbiol 76(8):939-949

Gregory AR (2018) Global, regional, and national age-sex-specific mortality for 282 causes of death in 195 countries and territories, 1980-2017: a systematic analysis for the Global Burden of Disease Study 2017. Lancet 392(10159):1736-1788. https://doi. org/10.1016/s0140-6736(18)32203-7

Hall SR, Blundon HL, Ladda MA, Robertson AW, Martinez-Farina CF, Jakeman DL, Goralski KB (2015) Jadomycin breast cancer cytotoxicity is mediated by a copper-dependent, reactive oxygen species-inducing mechanism. Pharmacol Res Perspect 3(2):110

Hameed I (2016) Analysis of volatile metabolites released by staphylococcus aureus using gas chromatography-mass spectrometry and determination of its antifungal activity. Orient $\mathrm{J}$ Chem 32(4):2107-2116. https://doi.org/10.13005/ojc/320439

Han L, Zheng CP, Sun YQ, Xu G, Wen W, Fu QL (2014) A bacterial extract of OM-85 Broncho-Vaxom prevents allergic rhinitis in mice. Am J Rhinol Allergy 28(2):110-116. https://doi.org/10. 2500/ajra.2013.27.4021

Hecht SM (2000) Bleomycin: new perspectives on the mechanism of action. J Nat Prod 63(1):158-168. https://doi.org/10.1021/ np990549f

Hong S, Moon BH, Yong Y, Shin SY, Lee YH, Lim Y (2008) Inhibitory effect against Akt of cyclic dipeptides isolated from Bacillus sp. J Microbiol Biotechnol 18(4):682-685

$\mathrm{Hu}$ Y, Martinez ED, MacMillan JB (2012) Anthraquinones from a marine-derived Streptomyces spinoverrucosus. J Nat Prod 75(10):1759-1764. https://doi.org/10.1021/np3004326

Hu C, Zhou SW, Chen F, Zheng XH, Shen HF, Lin BR, Zhou GX (2017) Neoantimycins A and B, two unusual benzamido ninemembered dilactones from marine-derived Streptomyces antibioticus $\mathrm{H} 12-15$. Molecules 22(4):557

Ibrahim AY, Youness ER, Mahmoud MG, Asker MS, El-Newary SA (2020) Acidic exopolysaccharide produced from marine Bacillus amyloliquefaciens 3MS 2017 for the protection and treatment of breast cancer. Breast Cancer. https://doi.org/10. 1177/1178223420902075

Igarashi Y, Mogi T, Yanase S, Miyanaga S, Fujita T, Sakurai H, Saiki I, Ohsaki A (2009) Brartemicin, an inhibitor of tumor cell invasion from the actinomycete Nonomuraea sp. J Nat Prod 72(5):980-982. https://doi.org/10.1021/np9000575

Igarashi M, Sawa R, Yamasaki M, Hayashi C, Umekita M, Hatano M, Fujiwara T, Mizumoto K, Nomoto A (2017) Kribellosides, novel RNA 5'-triphosphatase inhibitors from the rare actinomycete Kribbella sp. MI481-42F6. J Antibiot (tokyo) 70(5):582-589. https://doi.org/10.1038/ja.2016.161

Issa ME, Hall SR, Dupuis SN, Graham CL, Jakeman DL, Goralski KB (2014) Jadomycins are cytotoxic to ABCB1-, ABCC1-, and ABCG2-overexpressing MCF7 breast cancer cells. Anticancer Drugs 25(3):255-269. https://doi.org/10.1097/cad.0000000000 000043

Itoh T, Kinoshita M, Aoki S, Kobayashi M (2003) Komodoquinone A, a novel neuritogenic anthracycline, from marine Streptomyces sp. KS3. J Nat Prod 66(10):1373-1377. https://doi.org/ 10.1021/np030212k

Jeffrey MP, Strap JL, Jones Taggart H, Green-Johnson JM (2018) Suppression of intestinal epithelial cell chemokine production by Lactobacillus rhamnosus R0011 and Lactobacillus helveticus $\mathrm{R} 0389$ is mediated by secreted bioactive molecules. Front Immunol 9:2639. https://doi.org/10.3389/fimmu.2018.02639

Jeong SY, Han MH, Jin CY, Kim GY, Choi BT, Nam TJ, Kim SK, Choi YH (2010) Apoptosis induction of human leukemia cells by Streptomyces sp. SY-103 metabolites through activation of caspase-3 and inactivation of Akt. Int J Mol Med 25(1):31-40

Ji HF, Li XJ, Zhang HY (2009) Natural products and drug discovery. Can thousands of years of ancient medical knowledge lead us to new and powerful drug combinations in the fight against cancer and dementia? EMBO Rep 10(3):194-200. https://doi. org/10.1038/embor.2009.12

Jung HJ, Kim Y, Lee HB, Kwon HJ (2015) Antiangiogenic activity of the lipophilic antimicrobial peptides from an endophytic bacterial strain isolated from red pepper leaf. Mol Cells 38(3):273-278

Jurkiewicz D, Zielnik-Jurkiewicz B (2018) Bacterial lysates in the prevention of respiratory tract infections. Otolaryngol Pol 72(5):1-8. https://doi.org/10.5604/01.3001.0012.7216

Jurkiewicz E, Jansen R, Kunze B, Trowitzsch-Kienast W, Forche E, Reichenbach H, Höfle G, Hunsmann G (1992) Three new potent 
HIV-1 inhibitors from myxobacteria. Antivir Chem Chemother 3(4):189-193. https://doi.org/10.1177/095632029200300401

Kanekiyo K, Hayashi K, Takenaka H, Lee JB, Hayashi T (2007) Antiherpes simplex virus target of an acidic polysaccharide, nostoflan, from the edible blue-green alga Nostoc flagelliforme. Biol Pharm Bull 30(8):1573-1575. https://doi.org/10.1248/bpb.30. 1573

Karbalaei-Heidari HR, Partovifar M, Memarpoor-Yazdi M (2020) Evaluation of the bioactive potential of secondary metabolites produced by a new marine micrococcus species isolated from the Persian Gulf. Avicenna J Med Biotechnol 12(1):61-65

Khalifa SAM, Elias N, Farag MA, Chen L, Saeed A, Hegazy MF, Moustafa MS, Abd El-Wahed A, Al-Mousawi SM, Musharraf SG, Chang FR, Iwasaki A, Suenaga K, Alajlani M, Göransson U, El-Seedi HR (2019) Marine natural products: a source of novel anticancer drugs. Mar Drugs 17(9):491

Kim SH, Ha TK, Oh WK, Shin J, Oh DC (2016) Antiviral indolosesquiterpenoid xiamycins C-E from a halophilic actinomycete. J Nat Prod 79(1):51-58. https://doi.org/10.1021/acs.jnatprod. 5 b00634

Kim K, Kwon O, Ryu TY, Jung CR, Kim J, Min JK, Kim DS, Son MY, Cho HS (2019) Propionate of a microbiota metabolite induces cell apoptosis and cell cycle arrest in lung cancer. Mol Med Rep 20(2):1569-1574

Kodach LL, Bos CL, Durán N, Peppelenbosch MP, Ferreira CV, Hardwick JCH (2006) Violacein synergistically increases 5-fluorouracil cytotoxicity, induces apoptosis and inhibits Akt-mediated signal transduction in human colorectal cancer cells. Carcinogenesis 27(3):508-516. https://doi.org/10.1093/carcin/bgi307

Kovács T, Mikó E, Vida A, Sebő É, Toth J, Csonka T, Boratkó A, Ujlaki G, Lente G, Kovács P, Tóth D, Árkosy P, Kiss B, Méhes G, Goedert JJ, Bai P (2019) Cadaverine, a metabolite of the microbiome, reduces breast cancer aggressiveness through trace amino acid receptors. Sci Rep 9(1):1300. https://doi.org/10.1038/ s41598-018-37664-7

Krishnan K, Mani A, Jasmine S (2014) Cytotoxic activity of bioactive compound 1,2- benzene dicarboxylic acid, mono 2- ethylhexyl ester extracted from a marine derived Streptomyces sp. VITSJK8. Int J Mol Cell Med 3(4):246-254

Kristiana R, Bedoux G, Pals G, Mudianta IW, Taupin L, Marty C, Asagabaldan MA, Ayuningrum D, Trianto A, Bourgougnon N, Radjasa OK, Sabdono A, Hanafi M (2020) Bioactivity of compounds secreted by symbiont bacteria of Nudibranchs from Indonesia. PeerJ 8:e8093. https://doi.org/10.7717/peerj.8093

Kudo F, Eguchi T (2016) Aminoglycoside antibiotics: new insights into the biosynthetic machinery of old drugs. Chem Rec 16(1):4-18. https://doi.org/10.1002/tcr.201500210

Kusuhara S, Ito M, Sato T, Yokoi W, Yamamoto Y, Harada K, Ikemura H, Miyazaki K (2018) Intracellular GSH of Streptococcus thermophilus shows anti-oxidative activity against low-density lipoprotein oxidation in vitro and in a hyperlipidaemic hamster model. Benef Microbes 9(1):143-152. https://doi.org/10.3920/ BM2017.0065

Kyburz A, Urban S, Altobelli A, Floess S, Huehn J, Cover TL, Müller A (2017) Helicobacter pylori and its secreted immunomodulator VacA protect against anaphylaxis in experimental models of food allergy. Clin Exp Allergy 47(10):1331-1341. https://doi.org/10. 1111/cea.12996

Lalitha P, Veena V, Vidhyapriya P, Lakshmi P, Krishna R, Sakthivel $\mathrm{N}$ (2016) Anticancer potential of pyrrole $(1,2$, a) pyrazine 1 , 4, dione, hexahydro 3-(2-methyl propyl) (PPDHMP) extracted from a new marine bacterium, Staphylococcus $\mathrm{sp}$. strain MB30. Apoptosis 21(5):566-577

Law JW, Ser HL, Duangjai A, Saokaew S, Bukhari SI, Khan TM, Ab Mutalib NS, Chan KG, Goh BH, Lee LH (2017) Streptomyces colonosanans sp. nov., a novel actinobacterium isolated from malaysia mangrove soil exhibiting antioxidative activity and cytotoxic potential against human colon cancer cell lines. Front Microbiol 8:877

Law JW-F, Chan K-G, He Y-W, Khan TM, Ab Mutalib N-S, Goh B-H, Lee L-H (2019) Diversity of Streptomyces spp. from mangrove forest of Sarawak (Malaysia) and screening of their antioxidant and cytotoxic activities. Sci Rep 9(1):15262. https://doi.org/10. 1038/s41598-019-51622-x

Lee DK, Jang S, Kim MJ, Kim JH, Chung MJ, Kim KJ, Ha NJ (2008) Anti-proliferative effects of Bifidobacterium adolescentis SPM0212 extract on human colon cancer cell lines. BMC Cancer 8(310): 1471-2407

Lee YK, Mehrabian P, Boyajian S, Wu WL, Selicha J, Vonderfecht S, Mazmanian SK (2018) The protective role of bacteroides fragilis in a murine model of colitis-associated colorectal cancer. mSphere 3(6):00587-01518

Li T, Liu X, Shen Q, Yang W, Huo Z, Liu Q, Jiao H, Chen J (2016) Salinomycin exerts anti-angiogenic and anti-tumorigenic activities by inhibiting vascular endothelial growth factor receptor 2-mediated angiogenesis. Oncotarget 7(18):26580-26592

Lichtman SM (2013) Global initiatives to enhance cancer care in areas of limited resources: what ASCO members are doing and how you can become involved. Am Soc Clin Oncol Educ Book. https://doi.org/10.14694/EdBook_AM.2013.33.411

Lim HN, Jang JP, Han JM, Jang JH, Ahn JS, Jung HJ (2018) Antiangiogenic potential of microbial metabolite elaiophylin for targeting tumor angiogenesis. Molecules 23(3):563

Liu X, Gan M, Dong B, Zhang T, Li Y, Zhang Y, Fan X, Wu Y, Bai S, Chen M, Yu L, Tao P, Jiang W, Si S (2012) 4862F, a new inhibitor of HIV-1 protease, from the culture of Streptomyces I03A-04862. Molecules 18(1):236-243. https://doi.org/10.3390/ molecules 18010236

Liu L, Zhu H, Wu W, Shen Y, Lin X, Wu Y, Tang J, Zhou Y, Sun F, Lin HW (2019) Neoantimycin F, a streptomyces-derived natural product induces mitochondria-related apoptotic death in human non-small cell lung cancer cells. Front Pharmacol 10:1042

Lobo V, Patil A, Phatak A, Chandra N (2010) Free radicals, antioxidants and functional foods: impact on human health. Pharmacogn Rev 4(8):118-126. https://doi.org/10.4103/0973-7847.70902

Lomas DA, Lipson DA, Miller BE, Willits L, Keene O, Barnacle H, Barnes NC, Tal-Singer R (2012) An oral inhibitor of p38 MAP kinase reduces plasma fibrinogen in patients with chronic obstructive pulmonary disease. J Clin Pharmacol 52(3):416-424. https://doi.org/10.1177/0091270010397050

Maher PA (2020) Using plants as a source of potential therapeutics for the treatment of Alzheimer's disease. Yale J Biol Med 93(2):365-373

Marinelli F, Genilloud O, Fedorenko V, Ron EZ (2015) Specialized bioactive microbial metabolites: from gene to product. Biomed Res Int 2015:276964. https://doi.org/10.1155/2015/276964

Maruyama D, Tobinai K, Ogura M, Uchida T, Hatake K, Taniwaki M, Ando K, Tsukasaki K, Ishida T, Kobayashi N, Ishizawa K, Tatsumi Y, Kato K, Kiguchi T, Ikezoe T, Laille E, Ro T, Tamakoshi H, Sakurai S, Ohtsu T (2017) Romidepsin in Japanese patients with relapsed or refractory peripheral T-cell lymphoma: a phase I/II and pharmacokinetics study. Int J Hematol 106(5):655-665. https://doi.org/10.1007/s12185-017-2286-1

Matsuo Y, Kanoh K, Imagawa H, Adachi K, Nishizawa M, Shizuri Y (2007) Urukthapelstatin A, a novel cytotoxic substance from marine-derived Mechercharimyces asporophorigenens YM11542. II. Physico-chemical properties and structural elucidation. J Antibiot (tokyo) 60(4):256-260. https://doi.org/10.1038/ja. 2007.31 
Matsushita M, Kawaguchi M (2018) Immunomodulatory effects of drugs for effective cancer immunotherapy. J Oncol 2018:8653489. https://doi.org/10.1155/2018/8653489

Mazroui R, Sukarieh R, Bordeleau M-E, Kaufman R, Northcote P, Tanaka J, Gallouzi I, Pelletier J (2006) Inhibition of ribosome recruitment induces stress granule formation independently of eukaryotic initiation factor 2 phosphorylation. Mol Biol Cell 17:4212-4219. https://doi.org/10.1091/mbc.E06-04-0318

Meng Q, Li P, Li Y, Chen J, Wang L, He L, Xie J, Gao X (2019) Broncho-vaxom alleviates persistent allergic rhinitis in patients by improving Th1/Th2 cytokine balance of nasal mucosa. Rhinology 57(6):451-459. https://doi.org/10.4193/Rhin19.161

Meyer MP, Chow SSW, Alsweiler J, Bourchier D, Broadbent R, Knight D, Lynn AM, Patel H (2020) Probiotics for prevention of severe necrotizing enterocolitis: experience of New Zealand neonatal intensive care units. Front Pediatr 8:119. https://doi. org/10.3389/fped.2020.00119

Midhun S, Jyothis M (2021) Pharmacological applications of bioactive secondary metabolites from endophytes. Springer, Berlin, pp 71-89. https://doi.org/10.1007/978-981-15-9371-0_5

Mok SW, Wong VK, Lo HH, de Seabra RD, Leung EL, Law BY, Liu L (2020) Natural products-based polypharmacological modulation of the peripheral immune system for the treatment of neuropsychiatric disorders. Pharmacol Ther 208:107480. https://doi.org/10.1016/j.pharmthera.2020.107480

Molnár I, Schupp T, Ono M, Zirkle R, Milnamow M, NowakThompson B, Engel N, Toupet C, Stratmann A, Cyr DD, Gorlach J, Mayo JM, Hu A, Goff S, Schmid J, Ligon JM (2000) The biosynthetic gene cluster for the microtubule-stabilizing agents epothilones A and B from Sorangium cellulosum So ce90. Chem Biol 7(2):97-109. https://doi.org/10.1016/s10745521(00)00075-2

Molska M, Reguła J (2019) Potential mechanisms of probiotics action in the prevention and treatment of colorectal cancer. Nutrients 11(10): 2453

Moskowitz AJ, Horwitz SM (2017) Targeting histone deacetylases in T-cell lymphoma. Leuk Lymphoma 58(6):1306-1319. https:// doi.org/10.1080/10428194.2016.1247956

Nahui Palomino RA, Vanpouille C, Laghi L, Parolin C, Melikov K, Backlund P, Vitali B, Margolis L (2019) Extracellular vesicles from symbiotic vaginal lactobacilli inhibit HIV-1 infection of human tissues. Nat Commun 10(1):5656. https://doi.org/10.1038/ s41467-019-13468-9

Nakai A (2016) Heat shock factor. Springer, Berlin. https://doi.org/10. 1007/978-4-431-55852-1

Nakajima H, Kim YB, Terano H, Yoshida M, Horinouchi S (1998) FR901228, a potent antitumor antibiotic, is a novel histone deacetylase inhibitor. Exp Cell Res 241(1):126-133. https://doi.org/ 10.1006/excr.1998.4027

Nass NM, Farooque S, Hind C, Wand ME, Randall CP, Sutton JM, Seipke RF, Rayner CM, O’Neill AJ (2017) Revisiting unexploited antibiotics in search of new antibacterial drug candidates: the case of $\gamma$-actinorhodin. Sci Rep 7(1):17419. https://doi.org/ 10.1038/s41598-017-17232-1

Norden E, Heiss EH (2019) Urolithin A gains in antiproliferative capacity by reducing the glycolytic potential via the p53/TIGAR axis in colon cancer cells. Carcinogenesis 40(1):93-101

O'Brien VP, Hannan TJ, Nielsen HV, Hultgren SJ (2016) Drug and vaccine development for the treatment and prevention of urinary tract infections. Microbiol Spectr. https://doi.org/10.1128/micro biolspec.UTI-0013-2012

Pang B, Jong J, Qiao X, Wessels L, Neefjes J (2015) Chemical profiling of the genome with anti-cancer drugs defines target specificities. Nat Chem Biol. https://doi.org/10.1038/nchembio.1811

Pasquali C, Salami O, Taneja M, Gollwitzer ES, Trompette A, Pattaroni C, Yadava K, Bauer J, Marsland BJ (2014) Enhanced mucosal antibody production and protection against respiratory infections following an orally administered bacterial extract. Front Med (lausanne) 1:41. https://doi.org/10.3389/fmed.2014.00041

Passari AK, Mishra VK, Singh G, Singh P, Kumar B, Gupta VK, Sarma RK, Saikia R, Donovan AO, Singh BP (2017) Insights into the functionality of endophytic actinobacteria with a focus on their biosynthetic potential and secondary metabolites production. Sci Rep 7(1):017-12235

Patridge E, Gareiss P, Kinch MS, Hoyer D (2016) An analysis of FDAapproved drugs: natural products and their derivatives. Drug Discov Today 21(2):204-207. https://doi.org/10.1016/j.drudis. 2015.01.009

Pham JV, Yilma MA, Feliz A, Majid MT, Maffetone N, Walker JR, Kim E, Cho HJ, Reynolds JM, Song MC, Park SR, Yoon YJ (2019) A review of the microbial production of bioactive natural products and biologics. Front Microbiol 10:1404

Piekarz RL, Frye R, Turner M, Wright JJ, Allen SL, Kirschbaum MH, Zain J, Prince HM, Leonard JP, Geskin LJ, Reeder C, Joske D, Figg WD, Gardner ER, Steinberg SM, Jaffe ES, Stetler-Stevenson M, Lade S, Fojo AT, Bates SE (2009) Phase II multi-institutional trial of the histone deacetylase inhibitor romidepsin as monotherapy for patients with cutaneous T-cell lymphoma. J Clin Oncol 27(32):5410-5417. https://doi.org/10.1200/jco.2008.21.6150

Pimentel MR, Molina G, Dionísio AP, Maróstica Junior MR, Pastore GM (2011) The use of endophytes to obtain bioactive compounds and their application in biotransformation process. Biotechnol Res Int 2011:576286. https://doi.org/10.4061/2011/576286

Plitzko B, Kaweesa EN, Loesgen S (2017) The natural product mensacarcin induces mitochondrial toxicity and apoptosis in melanoma cells. J Biol Chem 292(51):21102-21116

Pournejati R, Gust R, Karbalaei-Heidari HR (2019) An aminoglycoside antibacterial substance, S-137-R, produced by newly isolated Bacillus velezensis strain RP137 from the Persian Gulf. Curr Microbiol 76(9):1028-1037. https://doi.org/10.1007/ s00284-019-01715-7

Pucci C, Martinelli C, Ciofani G (2019) Innovative approaches for cancer treatment: current perspectives and new challenges. Ecancermedicalscience 13:961. https://doi.org/10.3332/ecancer.2019.961

Qu W, Kang YD, Zhou MS, Fu LL, Hua ZH, Wang LM (2010) Experimental study on inhibitory effects of histone deacetylase inhibitor MS-275 and TSA on bladder cancer cells. Urol Oncol 28(6):648654. https://doi.org/10.1016/j.urolonc.2008.11.018

Rambabu V, Suba S, Vijayakumar S (2015) Antimicrobial and antiproliferative prospective of kosinostatin: a secondary metabolite isolated from Streptomyces sp. J Pharm Anal 5(6):378-382

Rautela R, Singh AK, Shukla A, Cameotra SS (2014) Lipopeptides from Bacillus strain AR2 inhibits biofilm formation by Candida albicans. Antonie Van Leeuwenhoek 105(5):809-821. https:// doi.org/10.1007/s10482-014-0135-2

Raveh A, Delekta PC, Dobry CJ, Peng W, Schultz PJ, Blakely PK, Tai AW, Matainaho T, Irani DN, Sherman DH, Miller DJ (2013) Discovery of potent broad spectrum antivirals derived from marine actinobacteria. PLoS ONE 8(12):e82318. https://doi.org/10. 1371/journal.pone.0082318

Rendon-Rosales MÁ, Torres-Llanez MJ, González-Córdova AF, Hernández-Mendoza A, Mazorra-Manzano MA, Vallejo-Cordoba B (2019) In vitro antithrombotic and hypocholesterolemic activities of milk fermented with specific strains of Lactococcus lactis. Nutrients 11(9):2150. https://doi.org/10.3390/nu11092150

Repa A, Thanhaeuser M, Endress D, Weber M, Kreissl A, Binder C, Berger A, Haiden N (2015) Probiotics (Lactobacillus acidophilus and Bifidobacterium infantis) prevent NEC in VLBW infants fed breast milk but not formula [corrected]. Pediatr Res 77(2):381388. https://doi.org/10.1038/pr.2014.192

Riahi K, Hosni K, Raies A, Oliveira R (2019) Unique secondary metabolites of a Streptomyces strain isolated from extreme salty 
wetland show antioxidant and antibacterial activities. J Appl Microbiol 127(6):1727-1740. https://doi.org/10.1111/jam.14428

Richter SS, Kealey DE, Murray CT, Heilmann KP, Coffman SL, Doern GV (2003) The in vitro activity of daptomycin against Staphylococcus aureus and Enterococcus species. J Antimicrob Chemother 52(1):123-127. https://doi.org/10.1093/jac/dkg288

Romero F, Espliego F, Pérez Baz J, García de Quesada T, Grávalos D, de la Calle F, Fernández-Puentes JL (1997) Thiocoraline, a new depsipeptide with antitumor activity produced by a marine Micromonospora. I. Taxonomy, fermentation, isolation, and biological activities. J Antibiot (tokyo) 50(9):734-737. https://doi. org/10.7164/antibiotics.50.734

Rupasinghe HPV, Parmar I, Neir SV (2019) Biotransformation of cranberry proanthocyanidins to probiotic metabolites by Lactobacillus rhamnosus enhances their anticancer activity in HepG2 cells in vitro. Oxid Med Cell Longev 2019:4750795. https://doi.org/ 10.1155/2019/4750795

Sader HS, Streit JM, Fritsche TR, Jones RN (2004) Antimicrobial activity of daptomycin against multidrug-resistant gram-positive strains collected worldwide. Diagn Microbiol Infect Dis 50(3):201-204. https://doi.org/10.1016/j.diagmicrobio.2004.07. 002

Safarpour A, Ebrahimi M, Shahzadeh Fazeli SA, Amoozegar MA (2019) Supernatant metabolites from halophilic archaea to reduce tumorigenesis in prostate cancer in-vitro and in-vivo. Iran J Pharm Res 18(1):241-253

Sagar S, Esau L, Hikmawan T, Antunes A, Holtermann K, Stingl U, Bajic VB, Kaur M (2013) Cytotoxic and apoptotic evaluations of marine bacteria isolated from brine-seawater interface of the Red Sea. BMC Compl Altern Med 13(29):1472-6882

Sanchez J, Carter TR, Cohen MS, Blagg BSJ (2020) Old and new approaches to target the Hsp90 Chaperone. Curr Cancer Drug Targets 20(4):253-270. https://doi.org/10.2174/1568009619 666191202101330

Sánchez-Ramón S, Conejero L, Netea MG, Sancho D, Palomares Ó, Subiza JL (2018) Trained immunity-based vaccines: a new paradigm for the development of broad-spectrum anti-infectious formulations. Front Immunol 9:2936. https://doi.org/10.3389/ fimmu.2018.02936

Santos JD, Vitorino I, De la Cruz M, Diaz C, Cautain B, Annang F, Perez-Moreno G, Gonzalez Martinez I, Tormo JR, Martin JM, Urbatzka R, Vicente FM, Lage OM (2019) Bioactivities and extract dereplication of actinomycetales isolated from marine sponges. Front Microbiol 10:727. https://doi.org/10.3389/fmicb. 2019.00727

Schneider YK, Kine OH, Isaksson J, Ullsten S, Espen HH, Hammer AJ (2019) Anti-bacterial effect and cytotoxicity assessment of lipid 430 Isolated from Algibacter sp. Molecules. https://doi.org/10. 3390/molecules 24213991

Sebola TE, Uche-Okereafor NC, Tapfuma KI, Mekuto L, Green E, Mavumengwana V (2019a) Evaluating antibacterial and anticancer activity of crude extracts of bacterial endophytes from Crinum macowanii Baker bulbs. Microbiologyopen 8(12):e914. https://doi.org/10.1002/mbo3.914

Sebola TE, Uche-Okereafor NC, Tapfuma KI, Mekuto L, Green E, Mavumengwana V (2019b) Evaluating antibacterial and anticancer activity of crude extracts of bacterial endophytes from Crinum macowanii Baker bulbs. Microbiologyopen 8(12):17

Sekirov I, Russell SL, Antunes LC, Finlay BB (2010) Gut microbiota in health and disease. Physiol Rev 90(3):859-904. https://doi. org/10.1152/physrev.00045.2009

Ser HL, Tan LT, Law JW, Chan KG, Duangjai A, Saokaew S, Pusparajah P, Ab Mutalib NS, Khan TM, Goh BH, Lee LH (2017) Focused review: cytotoxic and antioxidant potentials of mangrove-derived streptomyces. Front Microbiol 8:2065
Siddiqui A, Iram F, Siddiqui S, Sahu K (2014) Role of natural products in drug discovery process. Int J Drug Dev Res 6:172-204

Siegel RL, Miller KD, Jemal A (2020) Cancer statistics, 2020. CA Cancer J Clin 70(1):7-30. https://doi.org/10.3322/caac.21590

Singh N, Bhattacharyya D (2014) Collagenases in an ether extract of bacterial metabolites used as an immunostimulator induces TNF- $\alpha$ and IFN- $\gamma$. Int Immunopharmacol 23(1):211-221. https:// doi.org/10.1016/j.intimp.2014.08.026

Singh S, Genilloud O, Peláez F (2010) Terrestrial microorganisms: filamentous bacteria. Compr Natl Prod 2:109-140

Singh M, Kumar A, Singh R, Pandey KD (2017) Endophytic bacteria: a new source of bioactive compounds. 3 Biotech 7(5):017-0942

Singh VK, Mishra A, Jha B (2019) 3-Benzyl-Hexahydro-Pyrrolo[1,2a]pyrazine-1,4-dione extracted from Exiguobacterium indicum showed anti-biofilm activity against pseudomonas aeruginosa by attenuating quorum sensing. Front Microbiol 10:1269. https:// doi.org/10.3389/fmicb.2019.01269

Stecchini ML, Del Torre M, Munari M (2001) Determination of peroxy radical-scavenging of lactic acid bacteria. Int J Food Microbiol 64(1-2):183-188. https://doi.org/10.1016/s0168-1605(00) 00456-6

Strobel G, Daisy B, Castillo U (2005) Novel natural products from rainforest endophytes. In: Zhang L, Demain AL (eds) Natural Products: Drug Discovery And Therapeutic Medicine. Humana Press, London, pp 329-351. https://doi.org/10.1007/978-159259-976-9_15

Sudha S, Masilamani SM (2012) Characterization of cytotoxic compound from marine sediment derived actinomycete Streptomyces avidinii strain SU4. Asian Pac J Trop Biomed 2(10):770-773

Tan LT, Chan CK, Chan KG, Pusparajah P, Khan TM, Ser HL, Lee LH, Goh BH (2019) Streptomyces sp. MUM256: a source for apoptosis inducing and cell cycle-arresting bioactive compounds against colon cancer cells. Cancers 11(11):1742

Teng Hern T, Chan K-G, Pusparajah P, Khan T, Lee LH, Goh BH (2019) Mangrove derived Streptomyces sp MUM265 as a potential source of antioxidant and anticolon-cancer agents. BMC Microbiol. https://doi.org/10.1186/s12866-019-1409-7

Thangaraju M, Gopal E, Martin PM, Ananth S, Smith SB, Prasad PD, Sterneck E, Ganapathy V (2006) SLC5A8 triggers tumor cell apoptosis through pyruvate-dependent inhibition of histone deacetylases. Cancer Res 66(24):11560-11564. https://doi.org/10. 1158/0008-5472.can-06-1950

Tobias J, Buxton EJ, Blackledge G, Mould JJ, Monaghan J, Spooner D, Chetiyawardana A (1990) Neoadjuvant bleomycin, ifosfamide and cisplatin in cervical cancer. Cancer Chemother Pharmacol 26(Suppl):S59-62. https://doi.org/10.1007/bf00685422

Totiger TM, Srinivasan S, Jala VR, Lamichhane P, Dosch AR, Gaidarski AA, Joshi C, Rangappa S, Castellanos J, Vemula PK, Chen X, Kwon D, Kashikar N, VanSaun M, Merchant NB, Nagathihalli NS (2019) Urolithin A, a novel natural compound to target PI3K/ AKT/mTOR pathway in pancreatic cancer. Mol Cancer Ther 18(2):301-311. https://doi.org/10.1158/1535-7163.mct-18-0464

Toussirot E, Robinet E, Saas P, Chabod J, Augé B, Cozma G, Tiberghien P, Roudier J, Wendling D (2006) Bacterial extract (OM-89) specific and non specific immunomodulation in rheumatoid arthritis patients. Autoimmunity 39(4):299-306. https:// doi.org/10.1080/08916930600738425

Triantafillou V, Workman AD, Patel NN, Maina IW, Tong CCL, Kuan EC, Kennedy DW, Palmer JN, Adappa ND, Waizel-Haiat S, Cohen NA (2019) Broncho-Vaxom ${ }^{\circledR}$ (OM-85 BV) soluble components stimulate sinonasal innate immunity. Int Forum Allergy Rhinol 9(4):370-377. https://doi.org/10.1002/alr.22276

Uche-Okereafor N, Sebola T, Tapfuma K, Mekuto L, Green E, Mavumengwana V (2019) Antibacterial activities of crude secondary metabolite extracts from pantoea species obtained from the stem 
of Solanum mauritianum and their effects on two cancer cell lines. Int J Environ Res Public Health. https://doi.org/10.3390/ ijerph16040602

Urrutia A, Garcia-Angulo VA, Fuentes A, Caneo M, Legue M, Urquiza S, Delgado SE, Ugalde J, Burdisso P, Calixto A (2020) Bacterially produced metabolites protect $C$. elegans neurons from degeneration. PLoS Biol 18(3):e3000638. https://doi.org/10. 1371/journal.pbio.3000638

Valipour B, Mohammadi SM, Abedelahi A, Maragheh FA, Maragheh FA, Naderali E, Dehnad A, Nozad CH (2018) Culture filtrate ether extracted metabolites from Streptomyces levis ABRIINW111 increased apoptosis and reduced proliferation in acute lymphoblastic leukemia. Biomed Pharmacother 108:216-223

Valles-Colomer M, Falony G, Darzi Y, Tigchelaar EF, Wang J, Tito RY, Schiweck C, Kurilshikov A, Joossens M, Wijmenga C, Claes S, Van Oudenhove L, Zhernakova A, Vieira-Silva S, Raes J (2019) The neuroactive potential of the human gut microbiota in quality of life and depression. Nat Microbiol 4(4):623-632. https://doi. org/10.1038/s41564-018-0337-X

van Wijck Y, John-Schuster G, van Schadewijk A, van den Oever RL, Obieglo K, Hiemstra PS, Müller A, Smits HH, Taube C (2019) Extract of Helicobacter pylori ameliorates parameters of airway inflammation and goblet cell hyperplasia following repeated allergen exposure. Int Arch Allergy Immunol 180(1):1-9. https:// doi.org/10.1159/000500598

Vanhaecke T, Papeleu P, Elaut G, Rogiers V (2004) Trichostatin A-like hydroxamate histone deacetylase inhibitors as therapeutic agents: toxicological point of view. Curr Med Chem 11(12):1629-1643. https://doi.org/10.2174/0929867043365099

Verschuere L, Rombaut G, Sorgeloos P, Verstraete W (2000) Probiotic bacteria as biological control agents in aquaculture. Microbiol Mol Biol Rev 64(4):655-671. https://doi.org/10.1128/mmbr. 64.4.655-671.2000

Vigushin DM, Ali S, Pace PE, Mirsaidi N, Ito K, Adcock I, Coombes RC (2001) Trichostatin A is a histone deacetylase inhibitor with potent antitumor activity against breast cancer in vivo. Clin Cancer Res 7(4):971-976

Wada S, Kubota Y, Sawa R, Umekita M, Hatano M, Ohba S, Hayashi C, Igarashi M, Nomoto A (2015) Novel autophagy inducers lentztrehaloses A B and C. J Antibiot 68(8):521-529

Wade D, Cooper J, Derry F, Taylor J (2019) Uro-Vaxom ${ }^{\circledR}$ versus placebo for the prevention of recurrent symptomatic urinary tract infections in participants with chronic neurogenic bladder dysfunction: a randomised controlled feasibility study. Trials 20(1):223. https://doi.org/10.1186/s13063-019-3275-x

Wang Y, Wu Y, Xu H, Mei X, Yu D, Li W (2017) Antioxidant properties of probiotic bacteria. Nutrients. https://doi.org/10.3390/ nu9050521

Wang CZ, Zhang CF, Luo Y, Yao H, Yu C, Chen L, Yuan J, Huang WH, Wan JY, Zeng J, Sawadogo WR, Yuan CS (2020) Baicalein, an enteric microbial metabolite, suppresses gut inflammation and cancer progression in Apc(Min/+) mice. Clin Transl Oncol 22(7):1013-1022

Warda AK, Rea K, Fitzgerald P, Hueston C, Gonzalez-Tortuero E, Dinan TG, Hill C (2019) Heat-killed lactobacilli alter both microbiota composition and behaviour. Behav Brain Res 362:213-223. https://doi.org/10.1016/j.bbr.2018.12.047

Warda AK, de Almeida Bettio PH, Hueston CM, Di Benedetto G, Clooney AG, Hill C (2020) Oral administration of heat-treated lactobacilli modifies the murine microbiome and reduces. Front Microbiol 11:69. https://doi.org/10.3389/fmicb.2020.00069
Wittayapipath K, Yenjai C, Prariyachatigul C, Hamal P (2020) Evaluation of antifungal effect and toxicity of xanthyletin and two bacterial metabolites against Thai isolates of Pythium insidiosum. Sci Rep 10(1):4495. https://doi.org/10.1038/s41598-020-61271-0

Yamasaki S, Kada A, Nagai H, Yoshida I, Choi I, Saito AM, Iwasaki H (2019) Phase II trial using romidepsin after gemcitabine, dexamethasone, and cisplatin therapy in elderly transplant-ineligible patients with relapsed/refractory peripheral T-cell lymphoma: study protocol. Acta Med Okayama 73(5):469-474. https://doi. org/10.18926/amo/57379

Yang SC, Sung PJ, Lin CF, Kuo J, Chen CY, Hwang TL (2014) Antiinflammatory effects of secondary metabolites of marine Pseudomonas sp. in human neutrophils are through inhibiting P38 MAPK, JNK, and calcium pathways. PLoS ONE 9(12):e114761. https://doi.org/10.1371/journal.pone.0114761

Yingchoncharoen P, Kalinowski DS, Richardson DR (2016) Lipidbased drug delivery systems in cancer therapy: what is available and what is yet to come. Pharmacol Rev 68(3):701-787. https:// doi.org/10.1124/pr.115.012070

Zhang WJ, Ohnishi K, Yoshida H, Pan L, Maksumova L, Muratkhodjaev F, Luo JM, Shigeno K, Fujisawa S, Naito K, Nakamura S, Shinjo K, Takeshita A, Ohno R (2000) Spicamycin and KRN5500 induce apoptosis in myeloid and lymphoid cell lines with down-regulation of bcl-2 expression and modulation of promyelocytic leukemia protein. Jpn J Cancer Res 91(6):604-611. https://doi.org/10.1111/j.1349-7006.2000.tb00988.x

Zhang J, Shen Y, Liu J, Wei D (2005) Antimetastatic effect of prodigiosin through inhibition of tumor invasion. Biochem Pharmacol 69(3):407-414. https://doi.org/10.1016/j.bcp.2004.08.037

Zhang X, Jiang SJ, Shang B, Jiang HJ (2015) Effects of histone deacetylase inhibitor trichostatin A combined with cisplatin on apoptosis of A549 cell line. Thorac Cancer 6(2):202-208. https://doi. org/10.1111/1759-7714.12167

Zhang X, Ye X, Chai W, Lian XY, Zhang Z (2016) New Metabolites and bioactive actinomycins from marine-derived Streptomyces sp. ZZ338. Mar Drugs 14(10):181

Zhang W, Che Q, Tan H, Qi X, Li J, Li D, Gu Q, Zhu T, Liu M (2017) Marine Streptomyces sp. derived antimycin analogues suppress HeLa cells via depletion HPV E6/E7 mediated by ROS-dependent ubiquitin-proteasome system. Sci Rep 7:42180

Zheng N, Gao Y, Zhu W, Meng D, Walker W (2020) Short chain fatty acids produced by colonizing intestinal commensal bacterial interaction with expressed breast milk are anti-inflammatory in human immature enterocytes. PLoS ONE 15:e0229283. https:// doi.org/10.1371/journal.pone.0229283

Zhou S, Yu Z, Chu W (2019) Effect of quorum-quenching bacterium Bacillus sp. QSI-1 on protein profiles and extracellular enzymatic activities of Aeromonas hydrophila YJ-1. BMC Microbiol 19(1):135. https://doi.org/10.1186/s12866-019-1515-6

Zhu B, Li Z, Qian P-Y, Herrup K (2020) Marine bacterial extracts as a new rich source of drugs against Alzheimer's disease. J Neurochem 152(4):493-508. https://doi.org/10.1111/jnc.14847

Publisher's Note Springer Nature remains neutral with regard to jurisdictional claims in published maps and institutional affiliations. 